\title{
From archeological layers to schematic rock art? Integrated study of the Neolithic pigments and pigmented rocks at the Rocher du Château (Western Alps, Savoie, France)
}

\author{
Claudia Defrasne ${ }^{1,2}$, Emilie Chalmin $^{3}$, Ludovic Bellot-Gurlet ${ }^{4}$, Eric Thirault ${ }^{5}$, Guy André ${ }^{1,2}$ \\ 1 Aix Marseille Université, CNRS, Ministère de la Culture, LAMPEA (UMR 7269), Aix-en-Provence, France \\ 2 Maison Méditerranéenne des Sciences de l'Homme 5 rue du Château de l'Horloge, BP647, F-13090 Aix-en-Provence, \\ France \\ 3 Université Savoie Mont Blanc, CNRS, Ministère de la Culture, EDYTEM (UMR 5204), Bâtiment " Pôle Montagne ", 5 bd \\ de la mer Caspienne, 73376 Le Bourget du Lac cedex, France \\ 4 Sorbonne Université, CNRS, MONARIS (UMR 8233), Campus Pierre et Marie Curie, 4 place Jussieu, 75252 Paris, \\ France \\ 5 Université Lumière Lyon 2 - Department of History of Art \& Archaeology, Archeorient (UMR 5133), Maison de l'Orient et \\ de la Méditerranée Jean Pouilloux, 7 rue Raulin, 69365 Lyon cedex 07, France
}

\begin{abstract}
Post-glacial schematic rock paintings extend across the Iberian Peninsula to the Italian Piedmont. The Rocher du Château is one of the few Alpine sites with such painted figurations, located on a main transalpine route at 1750 m.a.s.l. in the Vallée de la Maurienne (Savoie, France). Archeological excavations in front of the painted panels revealed pigments and pigmented pebbles in archaeological levels attributed to the Neolithic Square Mouthed Pottery culture (SMP culture, 4600-4000 BC). The coexistence of pigments from archeological soils and rock paintings is rare in European prehistory and exceptional for the Neolithic period. The integrated study of these materials, barely attempted before, combined non-invasive in situ methods (digital microscopy and Raman spectroscopy) and analytical studies of micro-samples (SEM-EDX, XRD). The weathering process on the rock surface before and after the layer of paint was studied, and the mineralogical identification of the pigments was analyzed. Complementary physico-chemical analyses were conducted at several scales of observation to identify the composition of the excavated pigments and pigmented materials. Some of them proved to be anthropogenic blends combining hematite and charcoal of plant origin. This association has never before been identified in other prehistoric European archeological sites. Based on these data, the potential links between the pebbles, the production of pigments, and the rock paintings are discussed.
\end{abstract}

Keywords: Rock art, Neolithic, Schematic paintings, Raman spectroscopy, Pigment analysis.

\section{Introduction}

Schematic prehistoric rock paintings in rock shelters or caves are spread across the Iberian Peninsula as far as the Italian Piedmont. This transcultural graphic expression is composed of recognizable elements like human figures, deer and caprinae, and of a geometric and abstract figures (ramiforms, grids, dots, U-shaped figures...). These rock paintings, which share common location criteria and themes on a huge Mediterranean area, are mainly attributed to the Neolithic period from the archeological context when present and from comparisons between material culture and painted figures. However, the chronological issue remains difficult to address in the absence of absolute dating. One of the western Alps sites with such rock paintings, called the Rocher du Château (Bessans, Savoie, France), appeared as a key site to address this issue, as dated pigments and pigmented materials were discovered during test excavations. Such an association between archeological paintings and pigments is rare in European Prehistory and exceptional for the European Neolithic period. 
The Rocher du Château is one of nine known Alpine sites with schematic rock paintings. It is a glacial rock bar located at 1750 m.a.s.l. in the HauteMaurienne valley, close to very high passes leading to the Italian Piedmont. Rock paintings are located on a very high and impressive dark cliff of serpentinite (dark green metamorphic rock). Three campaigns of archeological test excavations were completed between 1997 and 2003 by E. Thirault (2004, 2008a, b), leading to the identification of a Neolithic occupation level with pigments and pigmented pebbles, dating back to $4600-4000 \mathrm{BC}$. The Rocher du Château thus appears as a key site to address chronological milestone to schematic rock paintings. This provides a unique opportunity to conduct an integrated study of the pigment materials from the site, to investigate the materials and preparation techniques of the pigments from the archeological layers and, by comparing their composition to the rock paintings, to contribute to the chronological debate of the schematic rock paintings. Could these paintings be associated with the 5th millennium BC occupation?

Moreover, these rock paintings are the only ones on a serpentinite surface known for southern France and the Alps. The cliff is currently covered by a combination of white and dark accretions. In some areas, the paintings are painted directly on the serpentinite surface, in other on the white accretion layers and lastly sometimes the pigments are present between some white crust layers. Consequently, significant taphonomic processes occurred before and after the realization of rock paintings, and it was thus essential to study these in order to ensure a holistic approach to the rock face.

A study combining non-invasive in situ methods (Raman spectroscopy, digital microscopy) and microsampling characterization (scanning electron microscopy coupled with energy dispersive X-ray detector (SEM-EDX) and X-ray diffraction (XRD)) was chosen to characterize pigments, the layer of paint, and the weathering accretions. These methods have proven to be complementary for the study of pigments and their interaction with weathering products of the rock surface (general methodology described in Chalmin and Huntley 2017).

\section{The post-glacial schematic paintings' chronological issue}

\section{The Rocher du Château and the schematic rock paintings}

Schematic rock art, first identified at the end of the eighteenth century in Spain and studied from 1910 onwards by $\mathrm{H}$. Breuil and J. Cabré, is known from the Iberian Peninsula to the western Alps (Breuil 19331935). In Spain, where schematic paintings coexist with what is called the "Levantine art", the adjective "schematic" was used from the time of the first discoveries to distinguish summarily executed figures, mainly reduced to their structure, from precise and finely depicted Levantine compositions. In southern France, although the first discovery of schematic paintings dates back to 1920 (Bellin 1979), their existence and antiquity were only accepted after the study by A. Glory in 1941 (Glory 1941; Hameau 2002), following the publication of the Iberian paintings by $\mathrm{H}$. Breuil. From the 1980s, this corpus was systematically studied by $\mathrm{Ph}$. Hameau. These schematic rock paintings seem to share common location criteria, mainly rock shelters with a southern exposure, particular topographies or impressive views on the surroundings, common themes, and the presence of intermittent water flows and a reddish rock surface (Hameau 2002). The main common themes are the human figure, characterized by a great diversity of shapes, animal figures (deer and caprinae when recognizable), and more geometrical and abstract figures like ramiforms, grids, or groups of dots, for example. Besides these figures, the corpus is composed of many simple marks in relation or not with some particular features of the rock surface (concretions, holes...). These rock paintings provide the formal characteristics of the schematic expression as produced and used by all human groups, including contemporary societies, and particularly a fast execution and an almost complete lack of scenes (Darras 1998). In southern France and the western Alps, 127 rock shelters and caves with schematic paintings are known so far. These paintings evidenced the use of a particular graphic expression by prehistoric people, schematism, and probably result from a great diversity of social practices performed in particular places of the environment.

Such schematic rock paintings are present in the alpine environment (Pons 1938; Ayroles and Porte 1984; Seglie and Ricchiardi 1988; Seglie et al. 1988; Gambari 1992; Gambari 1994; Nisbet 1994; Arcà 1995; Gambari 1995; Arcà 1999; Crosa Lenz 2001; Gambari et al. 2001; Gambari 2007; Arcà and Fossati 2012; De Giuli and Priuli 2012; Fossati 2013; Defrasne and Bailly 2014; Walsh et al. 2016). ${ }^{1}$ The Rocher du Château is one of these alpine sites, with a south-east exposure and a striking presence in the landscape (Figs. 1, 2, 3, and 4). It is known for a group of large red deer depicted in a right profile view, with oversized antlers, painted in a concave area of the cliff forming an east-facing niche (Fig. 5). The paintings were first mentioned in 1869 (Truchet 1869) and published in 1971 (Prieur 1971). In addition to the deer panel, other mostly schematic paintings (a circle of dots, anchor shapes, grids,

\footnotetext{
${ }^{1}$ The Gias delle Pitture (Tende, Alpes Maritimes, France) paintings are not considered here. The paintings were originally copied onto tracing paper in the 1990s and the imagery differs slightly from what is known from the other sites in southern France. This site requires further study.
} 


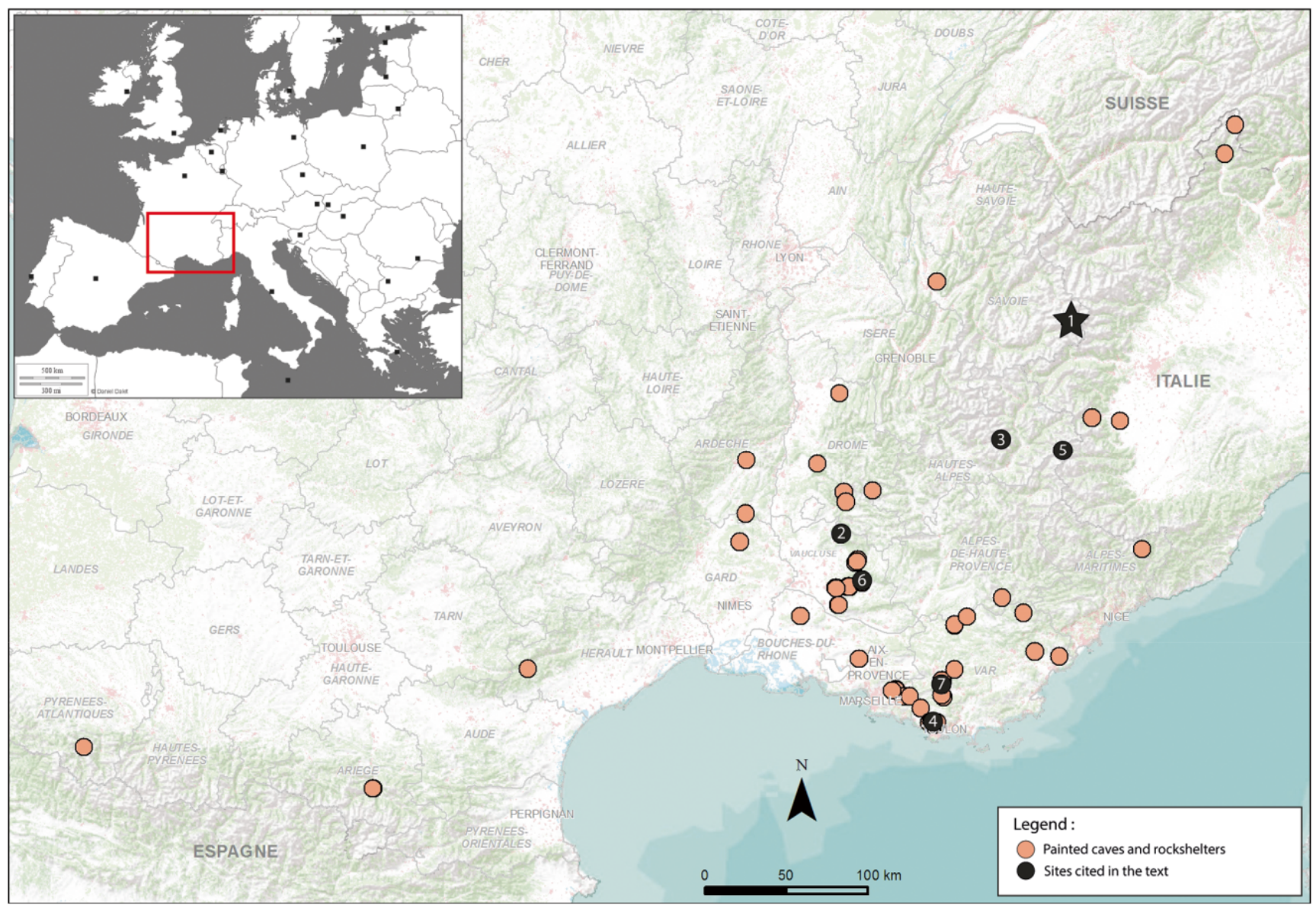

Fig. 1. Map showing the location of the Rocher du Château site (1), the sites with schematic paintings known in southern France and sites cited in the text: 2- Levant de Leaunier Cave (Malaucène, Vaucluse), 2- Faravel rock shelter (Freissinières, Hautes-Alpes), 3- Monier, Dumas and Sangliers caves

alignments of groups of three vertical lines, some finger-drawn forming comb-shaped and humanshaped figures) are spread over $80 \mathrm{~m}$ along the cliff (Figs. 6 and 7). Until now, the only record of all the paintings was the one by G. Nehl from 1975 (Nelh 1976). Since then, the rock paintings of Rocher du Château had not been reconsidered by archeologists.

In the scope of the study presented here, the rock paintings were recorded from digital photographs enhanced with the plug-in DStretch@ of the Image $J \circledR$ software according to a broadly used and described methodology (Harman 2005; Mark and Billo 2006; Quesada Martínez 2010; Domingo et al. 2013; Le Quellec et al. 2013; Defrasne 2014; Le Quellec et al. 2015; Fernández Ruiz and Spanedda 2013). Consequently, some new figures were identified, including four red deer, bringing the total number of red deer to 12, and other figures were better defined (Defrasne and Chalmin 2015). However, the paintings of the Rocher du Château are poorly preserved and because of being directly exposed to the outdoor aggression are doomed to disappear sooner or later. Others are completely covered by weathering by-products. In parallel with this 2D
(Ollioules, Var), 4- Oullas rock shelter (Saint-Paul-sur-Ubaye, Alpes-de-Haute-Provence), 5- Gayette rock shelter (Murs, Vaucluse), 6- Baume Saint Michel (Mazaugues, Var) and 7- Bergerie des Maigres (Signes, Var)

approach, photogrammetric coverage was taken to study the relationships between the paintings and the rock surface (Fig. 8).

\section{The need for chronological milestones}

One of the main challenges in the study of these schematic rock paintings is their chronology. Because no absolute dating could be done on the paintings themselves, the beginning and the duration of this phenomenon are not known. Consequently, chronological markers must be identified. In southern France, the chronological milestones which could be set from the environmental and archeological context or from the imagery itself are mainly situated between the 4th to the 3rd millennia BC.

The global environmental context is in favor of a Holocene chronology as some Alpine schematic paintings are located in areas covered by glaciers until the Younger Dryas cooling event.

With regards to archeological contexts from the material discovered in some painted sites, like flint tools and pottery, Ph. Hameau proposed an affiliation 


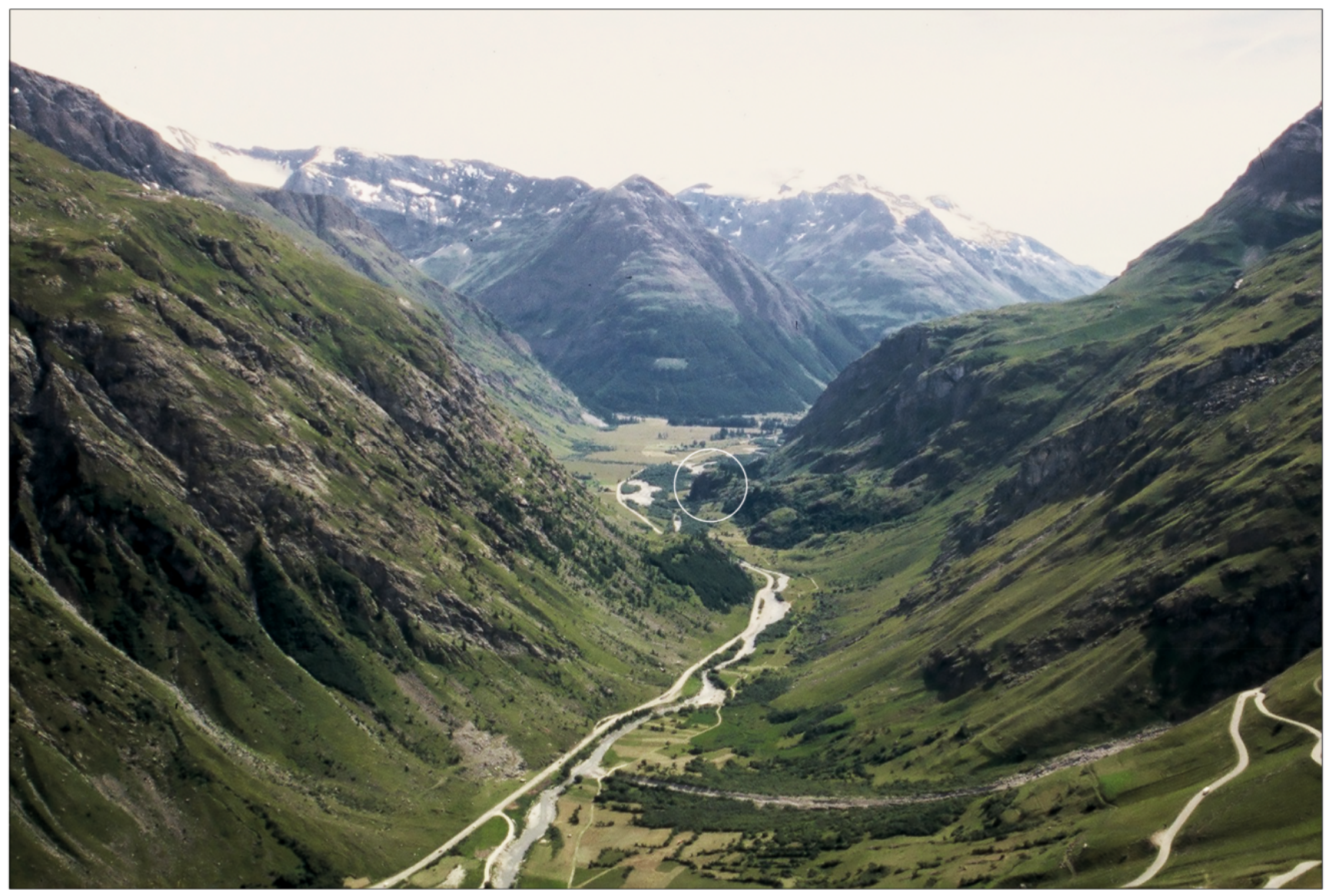

Fig. 2. View of the Rocher du Château site from the northern part of the valley (photo: E. Thirault)

of the rock paintings from the 4th to the 3rd millennia BC (Hameau 2002).

More specifically on the Levant du Leaunier site (Vaucluse, France), which may have been partly excavated for flint mining (De Labriffe et al. 2017; A. Reggio, personal communication November 11th, 2018), two sun-like figures and chevron patterns are painted on both sides of the negative of a flint nodule. Most of the production of the Vaucluse quarries dates back to the Middle Neolithic, but quarry exploitation may have begun during the early Neolithic and may have lasted until the 3rd millennium BC (De Labriffe et al. 2017).
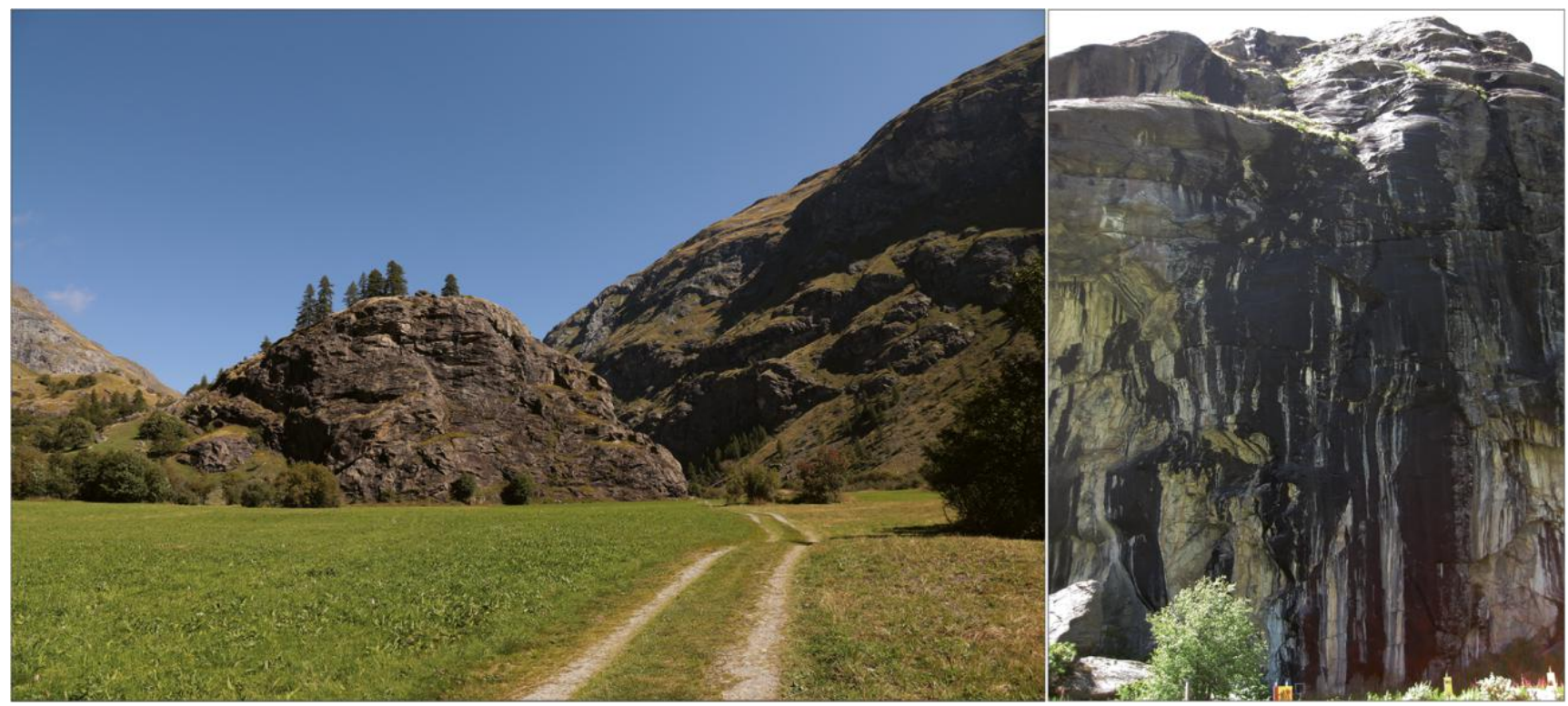

Fig. 3. Views of the Rocher du Château site from the south and the southeast (photos: C. Defrasne) 


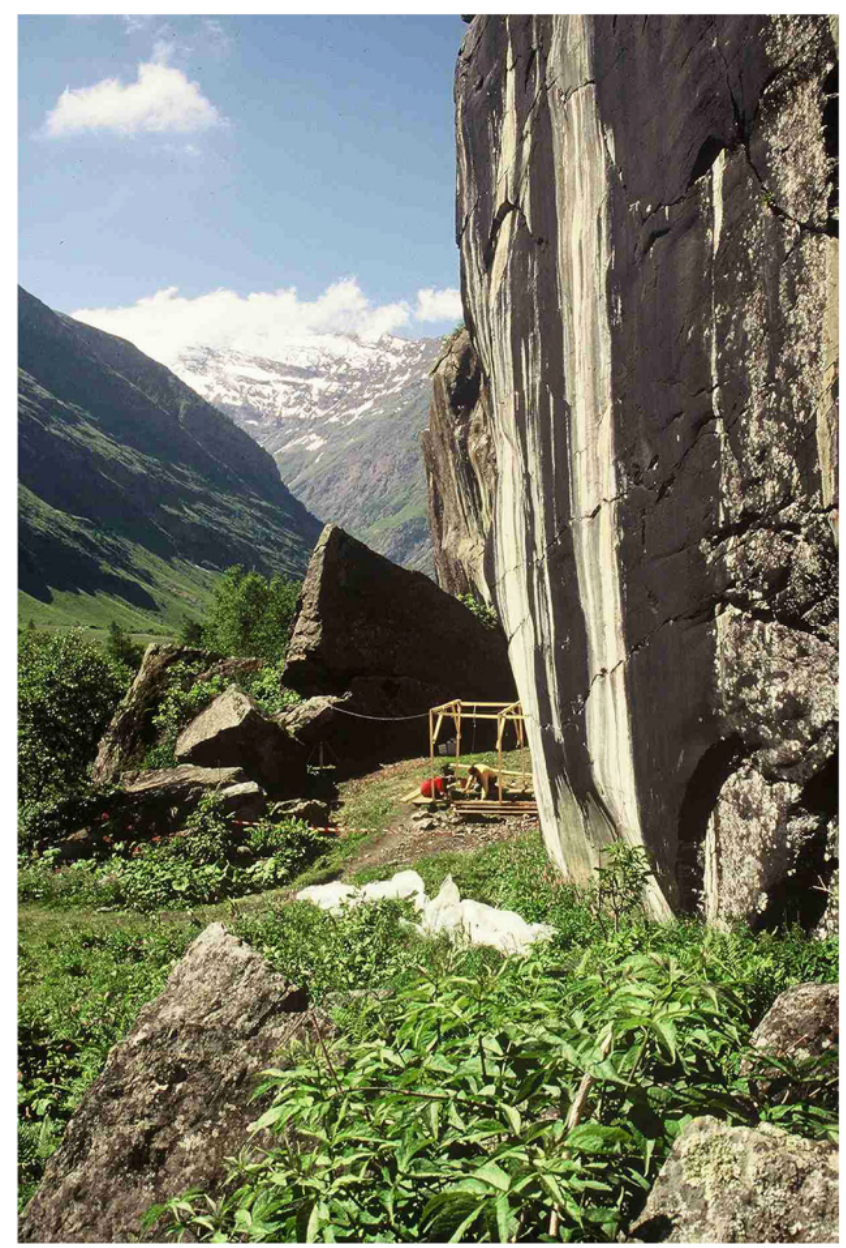

Fig. 4. Archeological excavation in front of the deer panel (photo: E. Thirault)

Moreover, a Middle Neolithic settlement (second half of the 5th millennium BC) was discovered in the cave. This provides a wide Neolithic context for these paintings.

Another context provides dating clues, the Faravel rock shelter (Ecrins National Park, Freissinières, Hautes-Alpes, France), which gives a terminus post quem. The figures are painted on the negative of a slab fallen on earlier Neolithic archeological layers (5295-5045 cal BC (Walsh et al. 2016; Defrasne et al. in press)).

Chronological milestones derived from the imagery are as follows.

The so-called Spanish "eye-idols", maybe also painted at the Donner rock shelter in southern France (Quinson, Alpes-de-Haute-Provence), are known from Middle Neolithic contexts and are, for example, much more characteristic of a period between the 5th and more frequently the 4th millennium to the beginning of the 3rd millennium BC (Ruiz et al. 2012).

An engraved and previously pigmented slab discovered during ancient excavations in the Monier Cave (Destel canyon, Var, France), a small cavity with schematic rock paintings also used as a burying place, is also worth mentioning. Its stratigraphic position is unclear, but engravings are reminiscent both of the T-shape figures of the painted schematic expression and the face of the anthropomorphic stelae dating back to the first half of the 4th millennium BC. In the same way, comparisons could be made between the shape of some anthropomorphic figures (the Dumas cave for example, Ollioules, Var, France) and the shape of the final Neolithic stelae. Moreover, such anthropomorphic engraved schist slabs, reminiscent of some schematic paintings, are widespread in the Iberian Peninsula from the 4th to the 3rd millennia BC (Hameau 1998; García Rivero et al. 2014).

At the Oullas site (Saint-Paul-sur-Ubaye, Alpes-deHaute-Provence, France), schematic paintings are covered by pecked Remedello-type daggers attributed to the first half of the 3rd millennium BC. This is a precise terminus ante quem for at least some of the schematic paintings (Müller et al. 2004; Defrasne and Bailly 2014).

Finally, the recent discovery and study of the imagery of the Gayette site (Murs, Vaucluse, France), composed of dotted meanders can be compared with British Neolithic grave engravings dating back to the 4th millennium BC (Defrasne and Hameau 2017).

Notwithstanding, some absolute dating has been attempted in Spain from calcium oxalates and points to a broader chronological range from 3630 to 3365 cal BC to 910-540 cal BC (Ruiz et al. 2012). However, these dates are still under debate as the technique has been reported as sometimes unreliable due to contamination of the oxalate crusts (Domingo Sanz 2008, 2015; Hernandez 2009; Mas et al. 2012).

In this context, the discovery of pigments and pigmented materials in the archeological layers of the Rocher du Château site, dated from the 5th millennium BC and attributed to the SMP culture, presents an opportunity to question the possible links between the paintings and these objects and to contribute to the chronological framing of the Bessans rock paintings. One of the purposes of the pigment analysis was to search for possible similarities between the paints and the excavated materials. Although it should be considered that the identical composition of pigments from dated archeological layers and paintings is not a direct proof of the age of the paintings, this would be an argument in favor of a relative dating which should remain a working hypothesis.

\section{From stratigraphy to rock surface: an unparalleled study}

Pigment analysis of schematic paintings have been performed both in the Iberian peninsula (LópezMontalvo et al. 2014, 2017; Gomes et al. 2015, 2017a, b; Rosina et al. 2018) and in southern France (Hameau et al. 1995; Hameau 2001, 2005). 


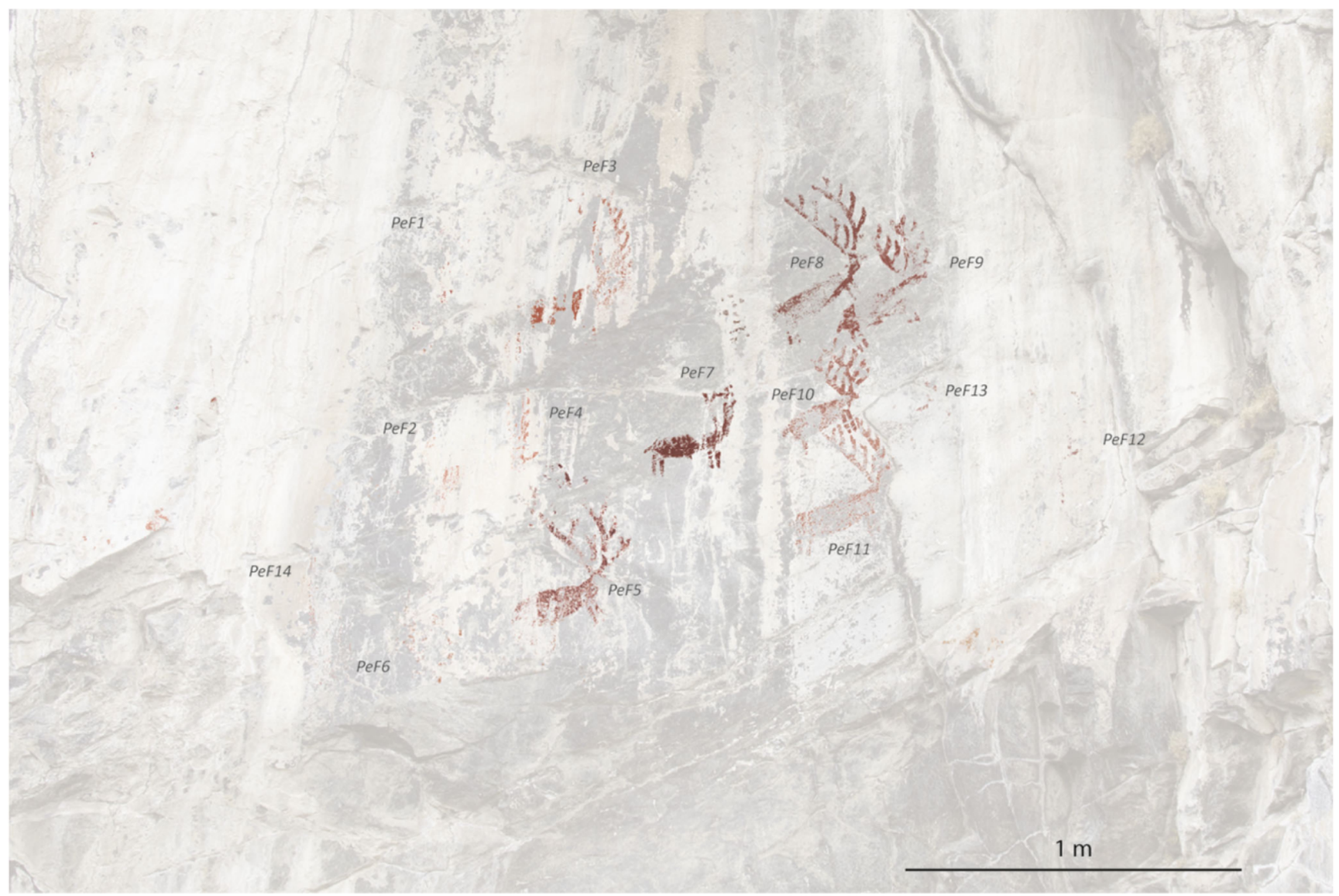

Fig. 5. Tracing of the red deer panel (CAD: C. Defrasne)

Indeed, Ph. Hameau directed pigment analyses on a hundred figures from different painted rock shelters evidencing the use of three main types of pigmenting matter (hematite, ochre, and bauxite) to which have been added talc, burned bones, or clay (Hameau et al. 1995; Hameau 2002, 2005). However, the copresence of dated archeological pigments and rock paintings is exceptional for European prehistory and more so for the Neolithic. Even if pigments have been found in archeological layers connected to European Paleolithic rock art such as Lascaux (Dordogne, Chalmin et al. 2004) or in the Grotte aux Points (Gard, Chanteraud et al. 2019), comparisons between the different materials used have not yet been proposed. Little research has focused on pigment production considering each step of the chaîne opératoire and have mostly covered the Paleolithic period (Chalmin et al. 2003; Pradeau et al. 2014; Cuenca-Solana et al. 2016; d'Errico et al. 2016). For the Neolithic, some analyses have been performed in the Iberian peninsula (Gomes et al. 2014, 2015) such as at la Cornisa de la Calderita, where pigment analyses was carried out on both the rock paintings and the red marks on lithic tools (Gomes et al. 2017a, b).

In southern France and the western Alps, very few rock art sites have preserved archeological layers (17 of the 123 sites, $13 \%$ ). Some of them were excavated many decades ago and pigments were probably not of interest at this time. From the 1980s, Ph. Hameau excavated other sites which sometimes revealed pigments. When no analyses were performed, the excavated pigments proved to have a different hue from the rock paintings. This is the case of pigments from the Baume Saint-Michel (Tourves, Var), the Monier Cave and the Grotte des Sangliers (Ollioules, Var), and the Resplandy Cave (Saint-Pons-deThomières) (Hameau 2005). At the Bergerie des Maigres site (Signes, Var), analyses allowed to compare excavated pigments with those of the rock paintings themselves. The pigments analyzed were different from the ones on the paintings with the possible exception of one (Hameau 2005, 2009). Without any micro-stratigraphy, the archeological remains are difficult to put into a precise chronological series. However, the material culture among which pigments have been identified is mainly attributed to the 3rd millennium BC, even if some ceramic sherds evidence a human presence during the early (Cardial) and Middle Neolithic (5th-4th mill. $\mathrm{BC}$ ). As a consequence, the analyses performed at the Rocher du Château site are the first ones comparing archeological pigments attributed to a precise archeological culture and rock paintings. 


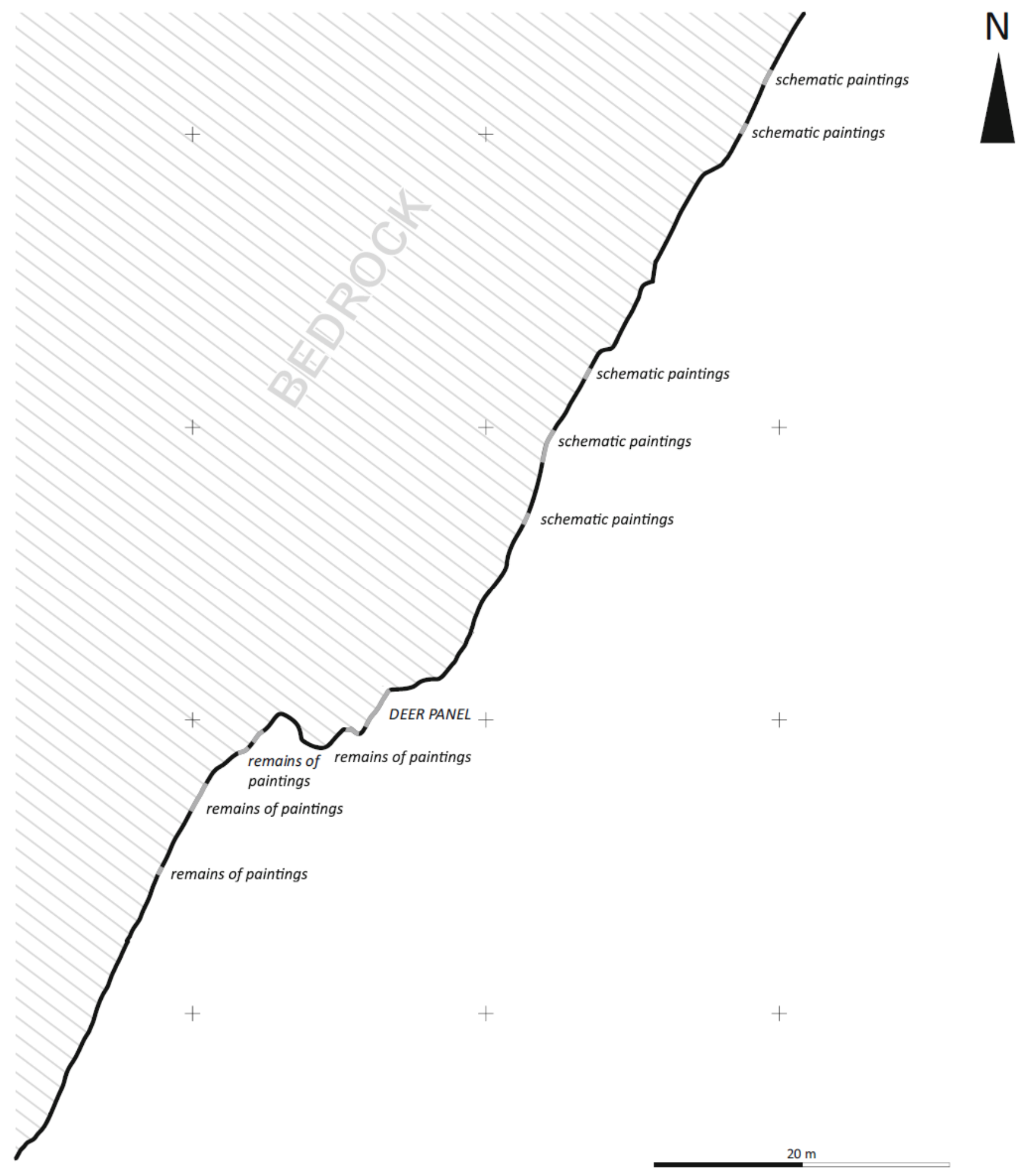

Fig. 6. Map of the south-western part of the cliff indicating the location of the paintings (CAD: C. Defrasne from topographic data by G. André)

\section{The Rocher du Château Neolithic site and its environment}

The Rocher du Château site (Bessans, Savoie, France) is located at 1750 m.a.s.l. in the Maurienne valley (Northern French Alps) (Figs. 1, 2, 3, and 4).
It is set on an old alluvial bank on the right side of the Arc River, which now flows $125 \mathrm{~m}$ away, and is constituted of an impressive southeast-facing rock face, about $80 \mathrm{~m}$ high and $150 \mathrm{~m}$ long (Thirault and Pallier 2006; Figs. 2, 3, and 6). The rock paintings and the archeological levels are located in the southwestern part of the cliff (Figs. 6 and 9). 

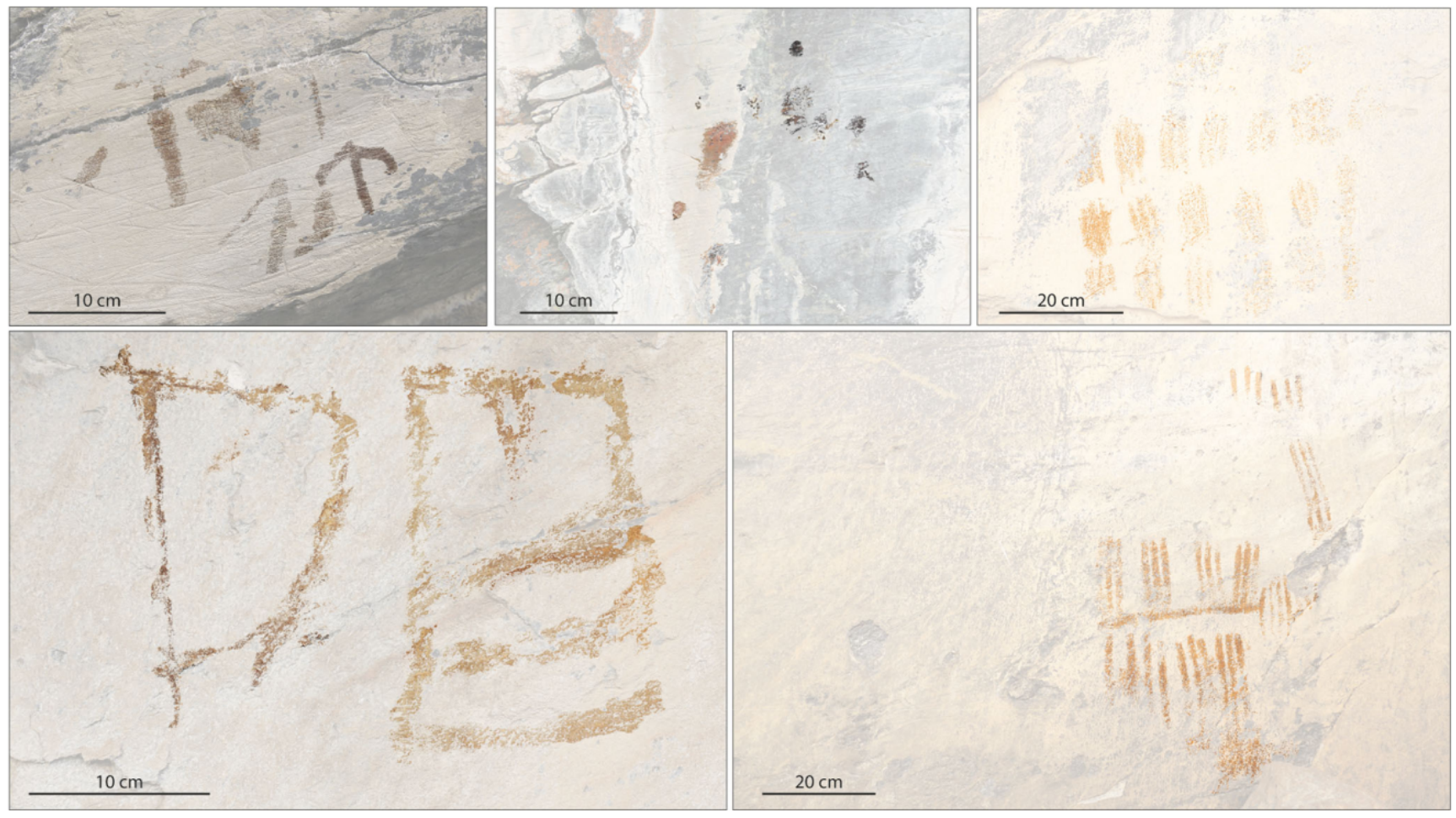

Fig. 7. Tracing of the best preserved paintings from the Rocher du Château site (CAD: C. Defrasne)

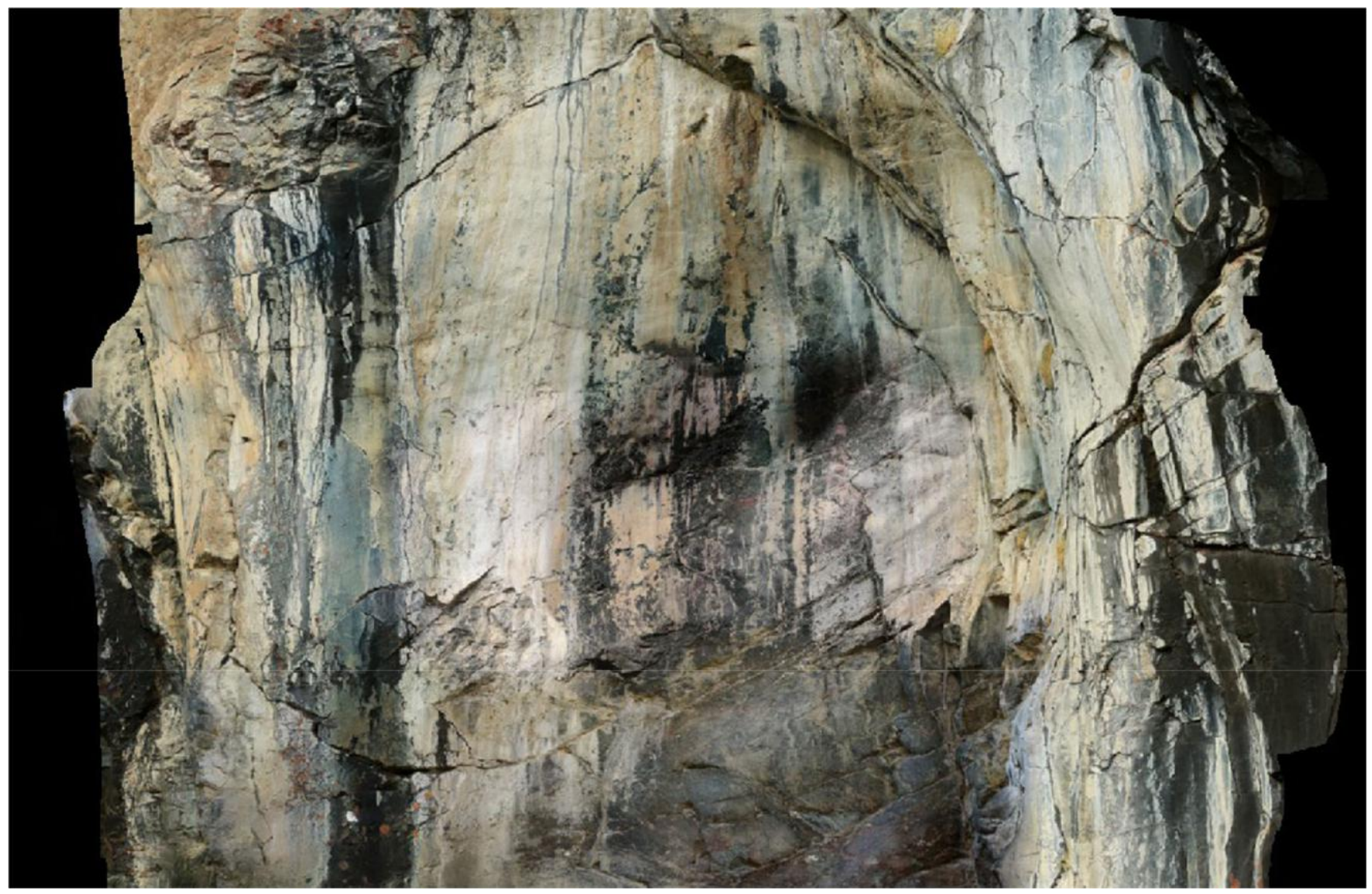

Fig. 8. Photogrammetry of the deer panel (CAD: G. André) 

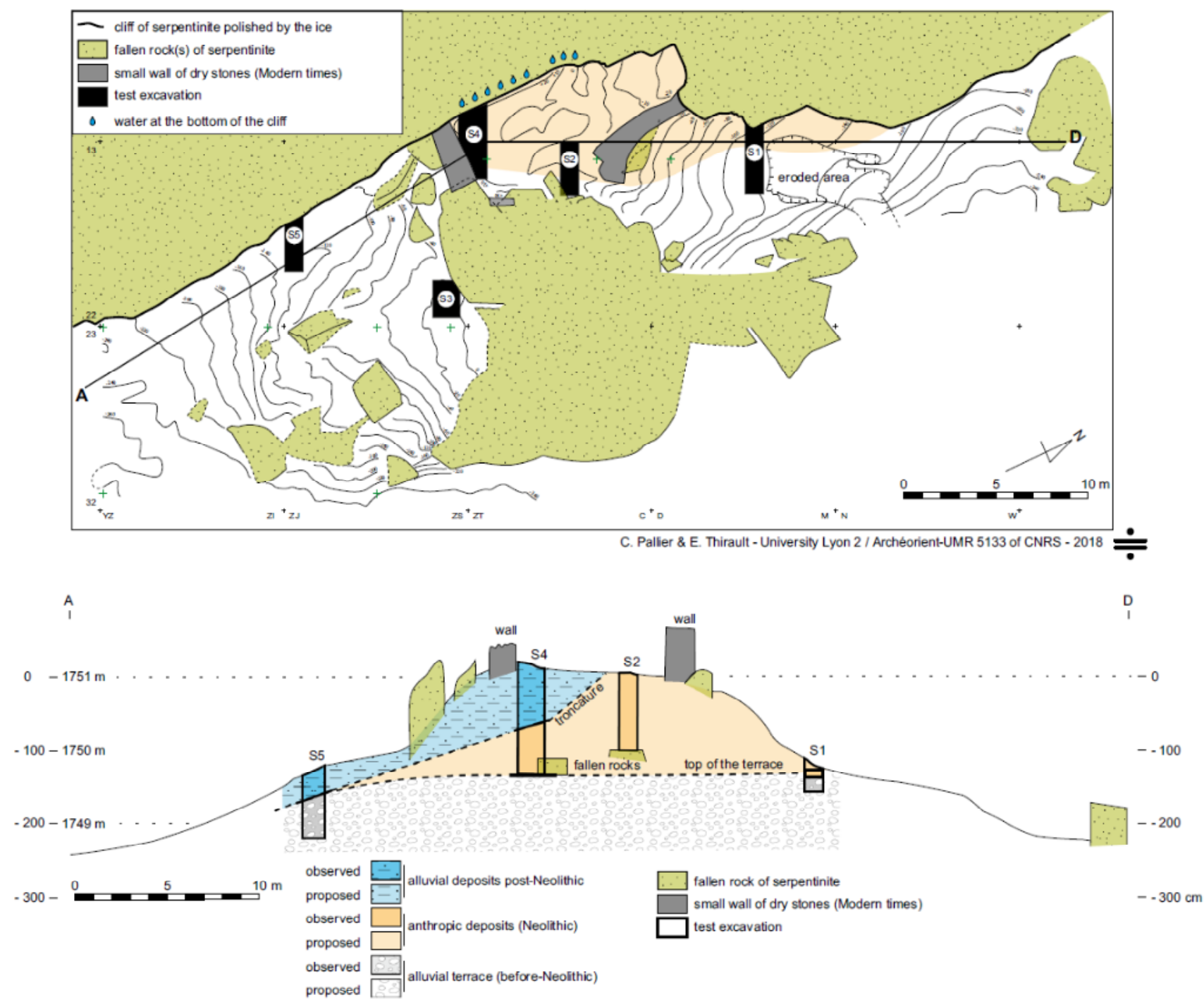

Fig. 9. Map and cross-section of the site with the location of the test excavations (CAD: C. Pallier and E. Thirault)

Numerous randomly heaped boulders, originating from former collapses, form scree, bordering the cliff in the northern part of the archeological site where some paintings are preserved. Most collapses can be dated approximately between 10000 BC (deglaciation) and $4600 \mathrm{BC}$ (Thirault and Pallier 2006) and consequently predate the Neolithic occupation and the creation of the paintings.

\section{A striking rock on a transalpine route}

The Rocher du Château is a glacial rock bar, emerging from the valley bottom and marking the transition between the Bessans paleolake (a plain today) and the narrow upper valley (Figs. 2 and 3 ). On account of this location, and the impressive dark cliff, the Rocher is a striking feature of the landscape.

The Maurienne valley is a main transalpine route from the Savoyard Piedmont to the Italian foothills. Along with the Tarentaise valley, this is a real transversal transect across the Alps (Marguet et al. 2008).
From prehistoric times onwards, this internal Alpine area was characterized by northern and Mediterranean cultural influences, visible through the excavated material culture, especially lithic arrowheads and ceramic vessels (Marguet et al. 2008). Neolithic settlements from 4600 to 3400 BC, discovered in the nearby Tarentaise, for example, and particularly in the Bozel site, provide evidence of influences from the Wallis (Switzerland), the Italian Alps, the Po Plain, and the Rhone valley (Marguet et al. 2008; Rey 2009, 2016). For the 3rd millennium BC, similar conclusions can be drawn from the excavation at the Balmes Cave at Sollières-Sardières in Maurienne (Vital and Benamour 2012). Transit is possible through large and deep valleys, but Neolithic human groups also had to cross the Alpine passes in altitudes comprised between 2000 to 3200 m.a.s.l. (Thirault 2006; Rey and Moulin 2011). The location of the Rocher du Château site, in an area characterized by various cultural influences during the Neolithic period, is essential to our understanding of the rock paintings. 
Indeed, the schematic rock paintings appear as a transcultural graphic expression spread across a huge geographical area. Understanding cultural influences is essential in order to investigate the dissemination of ideas expressed in such graphisms.

\section{Two Neolithic occupations of the site (4600-4000 $\mathrm{BC} / 3500-2300 \mathrm{BC})$}

Archeological excavations revealed two Neolithic occupations of the Rocher du Château site preserved between a protected area forming a small rock shelter at the left of the painted deer panel and the collapsed blocks. In 1977 and 1990, the discovery of objects at the foot of the deer panel boosted interest in the site. Five test excavations in 1997, 2002, and 2003 by one of the authors (ET) revealed the existence of stratified deposits over $1 \mathrm{~m}$ thick (Figs. 4 and 9). To date, the Rocher du Château provides the earliest evidence of humans crossing the Maurienne valley. The remains are well preserved, bringing insights into the activities of the groups who came to the Rocher. Human presence is attested throughout the Neolithic, from approximately 4600 to 2300 years $\mathrm{BC}$ in which two phases are well documented.

Radiocarbon ages obtained from charcoals place the first activities between 4600 and $4000 \mathrm{BC}$. The material culture (ceramics and lithics) is related to the Square Mouth Pottery culture (SMP), a well-known culture in northern Italy dated from 4800 to 3800 BC. The human groups who came to Bessans during this period were probably from the Italian Piedmont. They could either have come from the valleys close to Maurienne or from the Po plain. This is not surprising given the geographical position of the site. However, this implies crossing high altitude passes located at 3000-3200 m.a.s.I, above Bessans or Bonneval-surArc. Consequently, these people were confirmed mountain dwellers, with good knowledge of high mountain routes and resources. Hunting (especially ibex: Capra ibex L.) was important during this phase and was undoubtedly an incentive for human presence (study of the faunal remains by Léa Roux).

The second phase is attested between 3500 and 2300 BC: numerous flint arrowheads indicate that human groups used the site over a long period during the so-called final Neolithic. However, this does not mean that the occupation of the site was permanent. As for the previous period, it is likely that the Rocher du Château site served as a temporary shelter for part of the year. The study of arrowheads shows obvious influences from the southeast of France, southern Switzerland, and Italy (Thirault 2004). Hunting remains (bones, especially ibex) are abundant during the recent phases of the Neolithic period, but the shelter was also used for the production of arrowheads in polished metamorphic rocks: serpentinite was quarried on site to obtain projectile points which were then diffused in Savoie and in the Italian Piedmont (Thirault 2004, 2007; Padovan and Thirault 2007).

Test excavation no 1 (S1), in front of the natural alcove where the painted deer are located, revealed a flat-bottomed post-hole (named A2), within $1 \mathrm{~m}$ of the wall, dug in the alluvial terrace. It is filled by a homogeneous and compact brown-black sediment and three small serpentinite slabs arranged vertically in the filling. Its original diameter is estimated between 35 and $40 \mathrm{~cm}$. In a cruel twist of fate, this posthole was half destroyed when a tourist information panel, since removed, was installed. The dating of this posthole is relative: it is covered by an archeological layer attributed to at least the end of the 4th millennium BC (Thirault 2004). This discovery is interesting since this posthole could indicate the installation of a scaffold for the painting of the deer panel.

\section{Pigments or pigmented materials from the test excavations}

The discovery of pigments and pigmented pebbles in the archeological layers attributed to the SMP culture (4600-4000 BC) makes the Rocher du Château a key site in the study of schematic paintings and, more precisely, in questionning of their chronology. All the sediment from the excavations was sieved with 1.6 to $2 \mathrm{~mm}$ diameter mesh. Between the various identified items likely to be connected to the production of paint, distinction is done between (i) the potential pigments: fragments of rock with pigmenting properties (cohesive, brittle, or powder) and (ii) the tools for the preparation of the pigments, named "pigmented materials": pebbles with (a) trace(s) of pigment on the surface which could be compared to the powder applied.

Among the seven fragments of rock, five cohesive red and brown fragments were identified as pigments and two small rock pebbles with one or two pigmented facets as "pigmented materials", because of their color and/or their exogenous petrography (Fig. 10; cf. Table 1). Two of them came from test excavation 2 (S2) (Fig. 9), layers 10 and 15 (C10 and C15), which delivered objects from the SMP culture. Five others came from test excavation 4 (S4): three of them from layer 10 (C10), attributed to the SMP culture, two others from layer 7 (C7), which has been slightly modified by the passage of the river. Layer $\mathrm{C} 7$ may also be attributed to the SMP, but a mix of different levels is also possible.

The first two pigments are small (Table 1), gray, red, and compact (group 1: RDC01 and RDC02, Table 1). None of them present facetted surfaces or striations which could be due to anthropogenic action (Fig. 10). Three of the other cohesive materials present good pigmenting properties due to their friability and have a metallic sheen (group 2: RDC0305, Table 1). Anthropogenic actions cannot be observed due to the state of preservation of the three items as they become coarse powder during storage. 
Fig. 10. Macrophotographs of the pigments samples: a) RDC01, b) RDC03, and pigmented pebbles: $\mathrm{c}$ ) RDC06 and d) RDC07 (black scale represents $2 \mathrm{~mm}$ ) (photo: E. Chalmin)
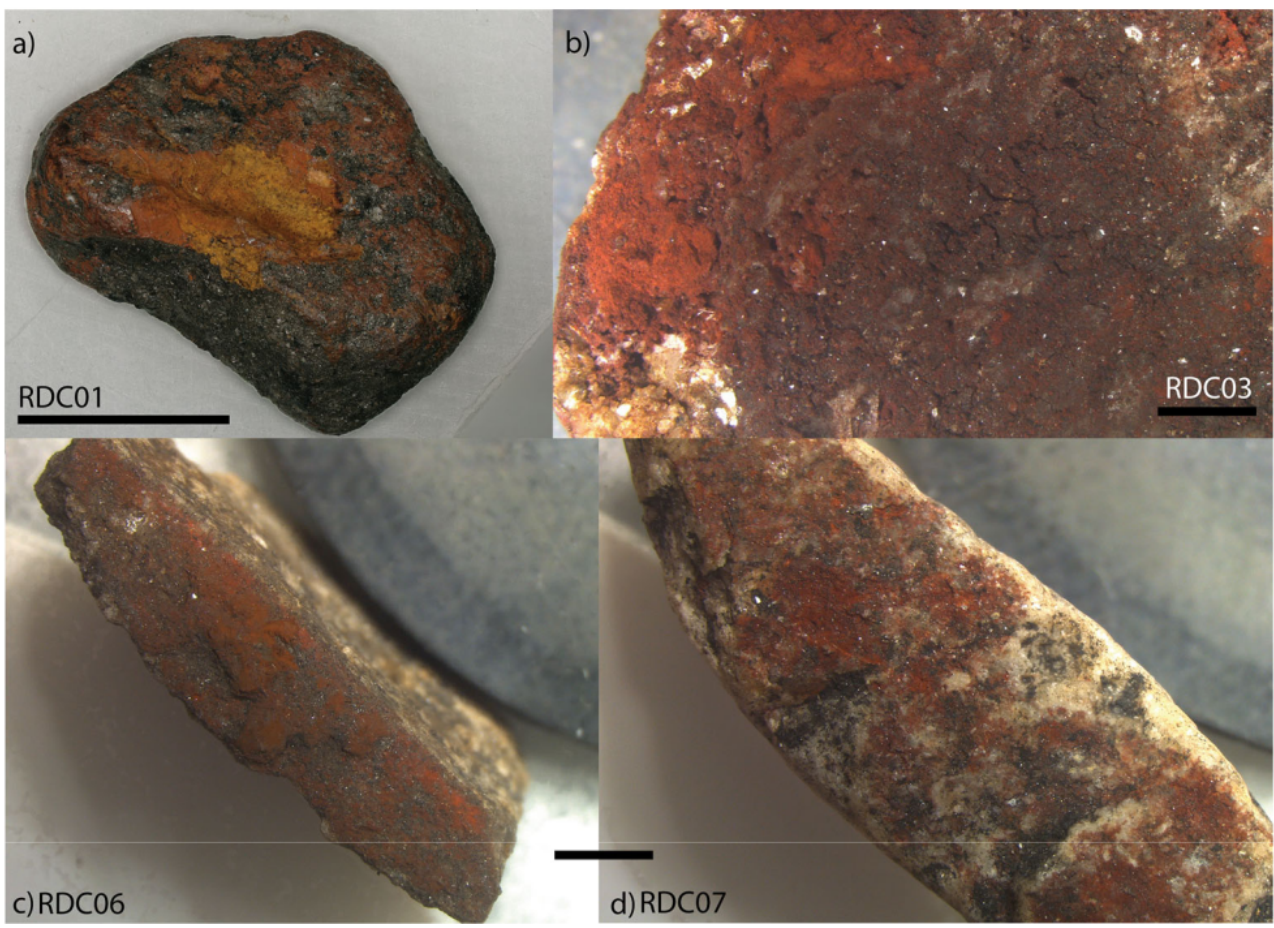

The two small pebbles called "pigmented materials" present one or two red-pigmented lateral surfaces (group 3: RDC06 and RDC07, white rows in Table 1, Fig. 10). The topography of the pigmented surfaces is uneven and does not present any marks of use or abrasion. Only modern post-excavation marks are visible resulting from the use of sharp metallic objects.

\section{Methodology for pigment analysis}

\section{On complementary methods}

To understand the presence of pigments and pigmented objects in an archeological site, an accurate description of these materials is required and should be adapted depending on their use and state. A distinction needs to be made between cohesive matter, pigmented surfaces of rock fragments, dispersed powder, or deposited powder. The Rocher du Château site contains several pigments and pigmented materials and tools in various states, which can be used to propose links and comparisons between them in order to provide archeological arguments.

To go further in the description of these objects, the use of a broad range of complementary methods is required (Chalmin and Huntley 2017; Chanteraud et al. 2019). Moreover, each method needs to be adapted to in situ measurements or laboratory analyses and presents some limitations. Indeed, onsite Raman spectroscopy only allows surface characterization. It is well adapted to the study of thin

Table 1. List and characteristics of coloring and colored matters coming from the excavation of the Rocher du Château (NS: not suitable)

\begin{tabular}{|c|c|c|c|c|c|c|c|c|}
\hline & $\mathbf{N}^{\circ}$ & Year & Square & Layer & Description & Size $(\mathrm{cm})$ & Color & $\begin{array}{l}\text { Coloring } \\
\text { property }\end{array}$ \\
\hline \multirow[t]{2}{*}{ Group 1} & RDC01 & 2003 & $\mathrm{~S} 2$ & $\mathrm{c} 15 \mathrm{~d} 1$ & Smooth compact nodule & $0.5 \times 0.3 \times 0.2$ & Shiny anthracite grey and red & Non tested \\
\hline & RDC02 & 2002 & $\mathrm{~S} 2$ & $\mathrm{cl0a}$ & $\begin{array}{l}\text { Compact nodule with sharp } \\
\text { featured edges }\end{array}$ & $0.8 \times 0.4 \times 0.3$ & Dark grey and bright red & Non tested \\
\hline \multirow[t]{3}{*}{ Group 2} & RDC03 & 2003 & S4 & $\mathrm{cl0} \mathrm{d} 4$ & Cohesive and friable matter and powder & $3.1 \times 2.1 \times 0.6$ and powder & Dark red and metallic grey & High \\
\hline & RDC04 & 2002 & S4 & $\mathrm{c} 7 \mathrm{~d} 2$ & Several cohesive friable matters & $2.5 \times 1.5 \times 0.5$ and powder & Dark red and metallic grey & High \\
\hline & RDC05 & 2002 & S4 & $\mathrm{c} 7 \mathrm{~d} 2 \mathrm{~b} 1$ & Several cohesive friable matters & $1.6 \times 0.8 \times 0.3$ and powder & Dark Brown and metallic sheen & High \\
\hline \multirow[t]{2}{*}{ Group 3} & RDC06 & 2003 & S4 & $\mathrm{c} 10 \mathrm{~d} 5$ & Pebble fragment & $1.2 \times 0.5 \times 0.2$ & $\begin{array}{l}\text { Grey pebble with two red lateral } \\
\text { faces }\end{array}$ & NS \\
\hline & RDC07 & 2003 & $\mathrm{~S} 4$ & $\mathrm{c} 10 \mathrm{~d} 5 / 6$ & Pebble fragment & $1.7 \times 0.7 \times 0.5$ & Grey pebble with one red lateral face & NS \\
\hline
\end{tabular}


pigmented layers and the products resulting from alteration processes. Raman spectroscopy, however, is not fully optimized for studying the stratigraphy without sampling, whereas sampling, conversely, allows for a detailed in-depth study of the layers. Where Raman spectroscopy provides a structural identification of the component, a complementary elemental analysis is required to determine the expected minor or trace elements allowing the study of provenance. This elemental analysis of paintings could not be fully achieved on site for the very thin pigmented layers. Therefore, sampling and SEMEDX were applied for morphological observation and elemental content measurement at the microscopic scale. Finally, XRD enabled the identification of the structure of the components and provided information about their crystallinity state.

\section{In situ methodology}

Using mesoscopic observations, it is possible to observe the distribution of the paint at the surface of white accretion layers or in the crevices of the bedrock surface. The mesoscopic observations were carried out with a digital microscope (Dino-lite edge AM4815ZT with a resolution of 1.3 megapixels, 1280 $x$ 1024), at magnifications of $x 32$ and $x 64$.

A thin layer of reprecipitated accretion is also occasionally observed over the layer of paint. Through mesoscopic observation, the accessibility of the paint can be evaluated in order to select pertinent areas for in situ Raman analysis and to perform the microsampling of the multi-layer crusts with and without paint at the surface of the bedrock (Fig. 11).

The color of the figures can be commented based on these high-resolution observations. Indeed, various reddish hues are observed according to the figures' location on the different panels, depending on the taphonomy. Indeed, these variations cannot be interpreted at this point since they depend on the color and the quality of the underlying surface (dark green of the bedrock (Fig. 11b) or white porous crust layer (Fig. 11a, c, d)), the potential covering crust layer(s) (crust as in Fig. 11c, d), and the leaching and the thickness of the paint layer (Fig. 11a). It consequently appears important to compare the color of the paint itself and not only the finished product so as to establish links or distinctions between the figures. Accordingly, a physico-chemical approach is required to compare various paints with high reliability.

On-site Raman characterization was performed with two modular mobile spectrometers with a different laser excitation wavelength each, one at 532 $\mathrm{nm}$ and the other at $785 \mathrm{~nm}$. The direct access to the site by car allowed for easy transportation of the two devices and a generator set for the power supply.
It was therefore possible to test on site the results obtained through the two configurations (ESM 1).

The HE532 spectrometer (Horiba Jobin Yvon) is based on a fixed parabolic 920 lines $/ \mathrm{mm}$ grating and a Peltier cooled CCD detector. In one acquisition, the spectrum is recorded between 80 and $3300 \mathrm{~cm}^{-1}$ with a spectral resolution of about $5 \mathrm{~cm}^{-1}$. The laser is a frequency doubled Nd:YAG laser at $532 \mathrm{~nm}$ (Ventus, Laser Quantum) and its power is adjusted in order to obtain about $150 \mu \mathrm{W}$ at the sample. The HE785 spectrometer (Horiba Jobin Yvon) integrates a fixed parabolic 685 lines $/ \mathrm{mm}$ grating and a Peltier cooled CCD detector. Its conception is also designed to obtain a spectral window between 80 and $3300 \mathrm{~cm}^{-1}$ in one acquisition with a resolution of about $5 \mathrm{~cm}^{-1}$. The laser is a AlGaAs diode (Process Instruments) emitting at $785 \mathrm{~nm}$ and the power is adjusted to about $300 \mu \mathrm{W}$ at the sample. It has been established that both used laser power respect the integrity of the analyzed sample (Bellot-Gurlet et al. 2009).

For both spectrometers, the Raman probe is a Horiba Jobin Yvon SuperHead which includes an Edge filter for Rayleigh rejection. Measurements are performed using microscope objectives, for the HE532 measurements a 50x Nikon ULWD (with a working distance of $17 \mathrm{~mm}$ ), and for the HE785 an infrared 40x Leitz LWD (working distance of $7 \mathrm{~mm}$ ). Spot sizes are, respectively, about $3 \mu \mathrm{m}$ and $18 \mu \mathrm{m}$. Laser, probe, and spectrometer are linked with $5 \mathrm{~m}$ optic fibers adapted to the wavelength.

As the paintings are high up, the measuring probes were positioned with a micrometric platform on a tripod placed on a small scaffolding. All spectra are corrected from the Edge filter contribution (Casadio et al. 2016) and baseline-corrected to remove the intense fluorescence contribution in order to be presented and properly interpreted.

\section{Micro-sample selection}

Based on the description of each figure and the accurate observation of the surface wall, authorization was obtained for three samples to be taken from the Deer panel: one from a non-decorated area (to be representative of the wall surface) and two others on the outline of two selected deer (Table 2). Sampling was carried out with a new sterilized scalpel for each point. During incision, the accretion presented high resistance due to its hardness, but a small fragment was removed and stored directly in a small microcentrifuge tube. As it is too difficult to remove with the scalpel a small sliver from the hard bedrock with a smooth surface, only the different accretion layers and painted matter were detached.

The exact location of the samples was recorded with a tacheometer and a macro-photograph of the sampled area was systematically taken (for example, sample RDC2016-P2 in Fig. 12). 


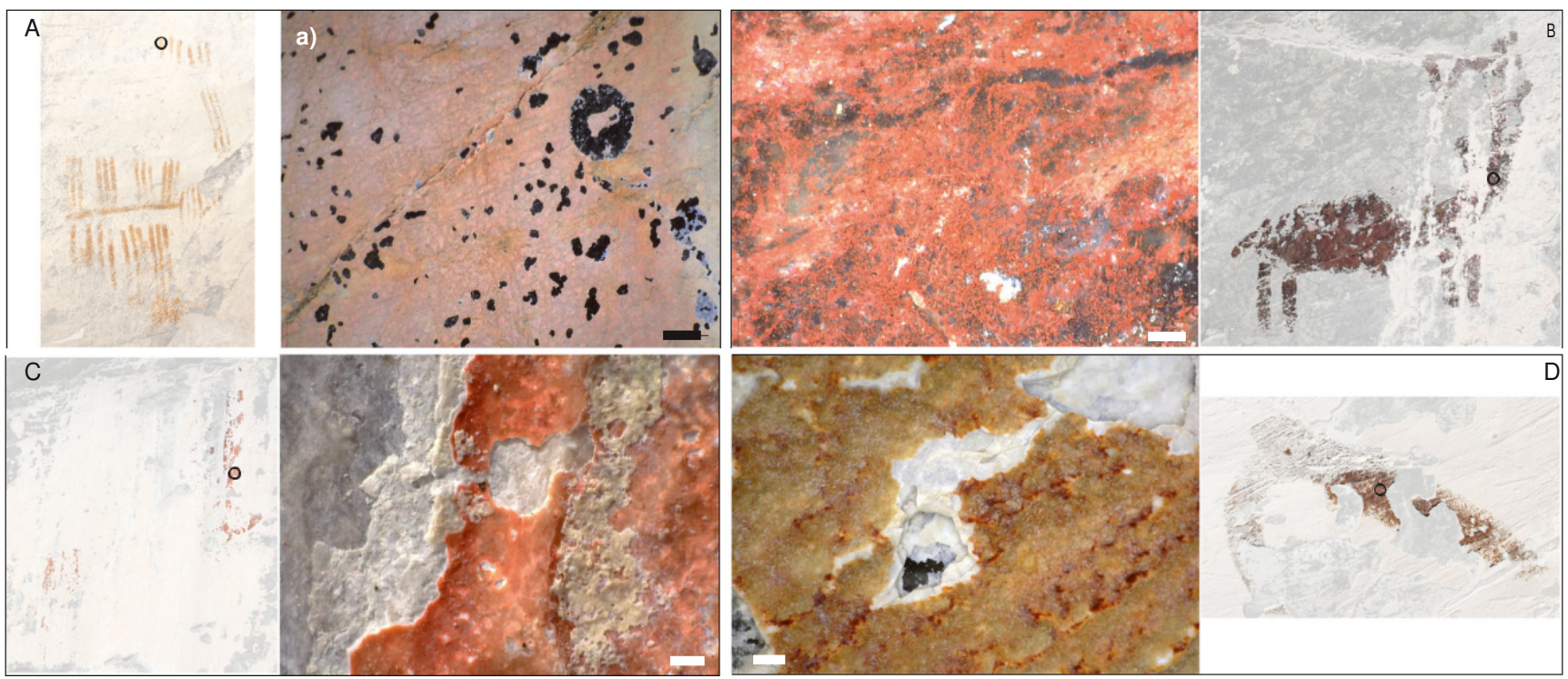

Fig. 11. Mesoscopic photographs of the painted bedrock surface presenting several crust layers (white scale represents $0.5 \mathrm{~mm}$, black scale $1 \mathrm{~mm}$ ) and location on the tracings (photo: E. Chalmin, tracings: C. Defrasne)

Table 2. List of the micro-samples obtained from the Deer panel (Rocher du Château) and the sample preparation performed

\begin{tabular}{llll}
\hline$N^{\circ}$ & Figure & Localization & Preparation \\
\hline RDC2016-P1 & White deposit & Small islet & SEM stub and polished cross-section \\
RDC2016-P2 & Deer ${ }^{\circ} 5$ & Left antler & SEM stub and polished cross-section \\
RDC2016-P3 & Deer ${ }^{\circ}{ }^{11}$ & Lower abdomen & SEM stub \\
\hline
\end{tabular}

Fig. 12. Location and macrophotographs of the microsample RDC2016-P2 from deer antler PeF5: a before and $b$ after sampling (black scale represents $1 \mathrm{~mm}$ ) (photo: E. Chalmin)

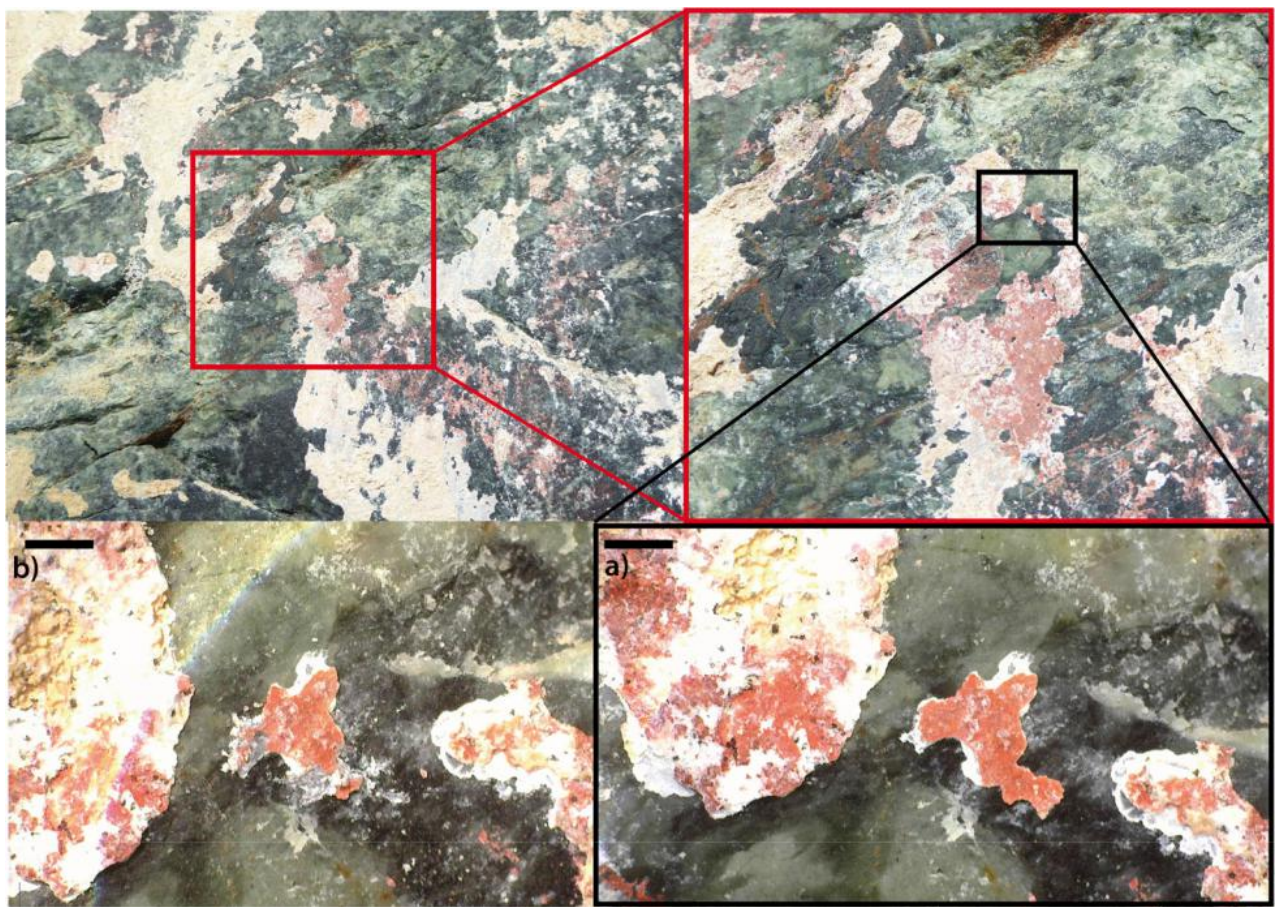


During sampling, two or three tiny slivers of accretion layers were detached from the wall surface.

\section{Laboratory methodology}

The analytical method used to study the samples and the excavated pigments and pigmented objects consists of observations with an optical microscope and then with a scanning electron microscope coupled with an energy dispersive X-ray detector (SEM-EDX), in order to visualize the micromorphology and to identify the chemical composition. Two different SEM-EDX were used:

- LEO STEREOSCAN 440 coupled with an X-ray analyzer SDD Bruker in high vacuum mode, beam voltage: between 10 and $20 \mathrm{keV}$, images obtained in secondary electron or backscattering electron modes (platform ASTRE, USMB),

- Zeiss Ultra+ (Z107) SEM-FEG (field emission gun) coupled with an X-ray analyzer SDD Bruker in high vacuum mode, beam voltage: between 5 and $15 \mathrm{keV}$, images obtained in secondary electron or backscattering electron modes (Institut Néel).

When the matter was compact, it was observed whole without any preparation. Only surface information was evaluated, except for the brittle materials (group 2: RDC03-05), where analyses were conducted in bulk. A tiny sliver of wall surface was selected from samples RDC2016-P1 and RDC2016P2. These slivers were embedded in epoxy resin and prepared as cross-sections in order to observe the stratigraphy of the various layers present. When powder was available, a small quantity was deposited on a carbon conductive adhesive tape stub. Carbon coating was applied only on the stubs and on the cross-sections of micro-samples before SEM-EDX analyses (for both instruments).

The powders were also prepared for X-ray diffraction analysis (XRD: INEL; $\mathrm{CoK}_{\alpha} \mathrm{X}$-ray tube; 1.5 $x 0.1$ slit; reflection mode; generator INEL XRG3D $30 \mathrm{~mA}, 30 \mathrm{kV}$; curved position sensitive detector INEL CPS120 with $0.08^{\circ}$ in resolution at FWHM) for real-time simultaneous data acquisition (acquisition time between 20 and $60 \mathrm{~min}$ ) in order to identify the crystalline minerals.

\section{Analysis of the rock paintings and the rock weathering}

In order to understand the interaction of the paint with the surface wall, it is important to study the taphonomy of the wall before and after the paintings. To this end, two complementary approaches involving in situ analyses and the study of microsamples were implemented for the Rocher du Château site.
In addition, a polished thin blade of serpentinite bedrock was observed under a polarized microscope.

\section{From the in situ analyses (cf. Fig. 11)}

The mesoscopic observation with the digital microscope of various painted areas enabled us to identify several accretion layers deposited on the bedrock surface which present different thicknesses, textures, and colors (Fig. 11c). During the formation of these accretion layers, paint was applied, consequently a newly formed layer of crust also covered the paint (Fig. 11c, d). This "massive tome" was then partially altered or destroyed either by partial dissolution, leading to an alveolar shape on the dark bedrock surface (Fig. 11a), or by a mechanical process causing flaking (such as a freeze/thaw cycle) with clear breaks (Fig. 11c, d).

In situ Raman spectroscopy enabled us to identify different alteration products in non-decorated and decorated areas. The slight presence of whewellite $\left(\mathrm{CaC}_{2} \mathrm{O}_{4} \cdot \mathrm{H}_{2} \mathrm{O}\right)$ was detected in some areas of deer no7 (Fig. 11). Its Raman signature was mixed with the signature of the pigment identified as hematite (see also Fig. 11) and the presented spectra underline the most intense presence of whewellite recorded on all the tested areas (Fig. 13). As whewellite is a good Raman diffuser, we can assume only a slight presence of this calcium oxalate that can be imputed to the metabolic activity of fungi or lichens.

On one painted area (Deer panel, antler of deer no5), diopside $\left(\mathrm{CaMgSi}_{2} \mathrm{O}_{6}\right)$ was identified (ESM 2). This diopside signature was also obtained for other areas from the decorated panel as well as on painted and blank surfaces (Fig. 13). Despite the fact that the diopside could be representative of the serpentinite bedrock, the observation of the thin blade does not reveal the presence of this kind of mineral. This metamorphic rock is mainly constituted by large altered crystals of serpentine minerals (general formulae $\left(\mathrm{Mg}, \mathrm{Fe}, \mathrm{Ni}_{3} \mathrm{Si}_{2} \mathrm{O}_{5}(\mathrm{OH})_{4}\right)$, crystals of the albite $\left(\mathrm{NaAlSi}_{3} \mathrm{O}_{8}\right)$ and chlorite group $\left((\mathrm{Fe}, \mathrm{Mg}, \mathrm{Al})_{6}\right.$ $\left.(\mathrm{Si}, \mathrm{Al})_{4} \mathrm{O}_{10}(\mathrm{OH})_{8}\right)$, very little epidote $\left(\mathrm{Ca}_{2} \mathrm{Al}_{2}\left(\mathrm{Fe}^{3+}\right.\right.$, $\left.\mathrm{Al})\left(\mathrm{SiO}_{4}\right)\left(\mathrm{Si}_{2} \mathrm{O}_{7}\right) \mathrm{O}(\mathrm{OH})\right)$, and some small opaque black crystals attributed to iron oxide or sulfide. However, the serpentinite bedrock in this geological context is described as an assembly of serpentine minerals (antigorite and chrysotile), talc, magnetite, chloride, and diopside. The fragment of serpentinite sampled to prepare the thin blade could be not representative of the totality of the various features of the serpentinite (Fudral et al. 1994).

On various areas of the painted surface, the signature of the pigment was clearly identified as hematite (Fig. 14). This is similar to other pigment analysis carried out on various prehistoric rock art sites, which points to the recurrent use of hematite as a major component of rock paintings (Hameau 2005; 
Fig. 13. On-site Raman spectra underlining the identification of whewellite (band labeled in bold) under the pigment signature (hematite, band labeled vertically in italics). Spectra are vertically scaled and shifted for presentation (excitation $532 \mathrm{~nm}$; pt20 and 22: $10 \mathrm{~s}$ x 10 acc., pt21: $60 \mathrm{~s}$ x 10 acc)

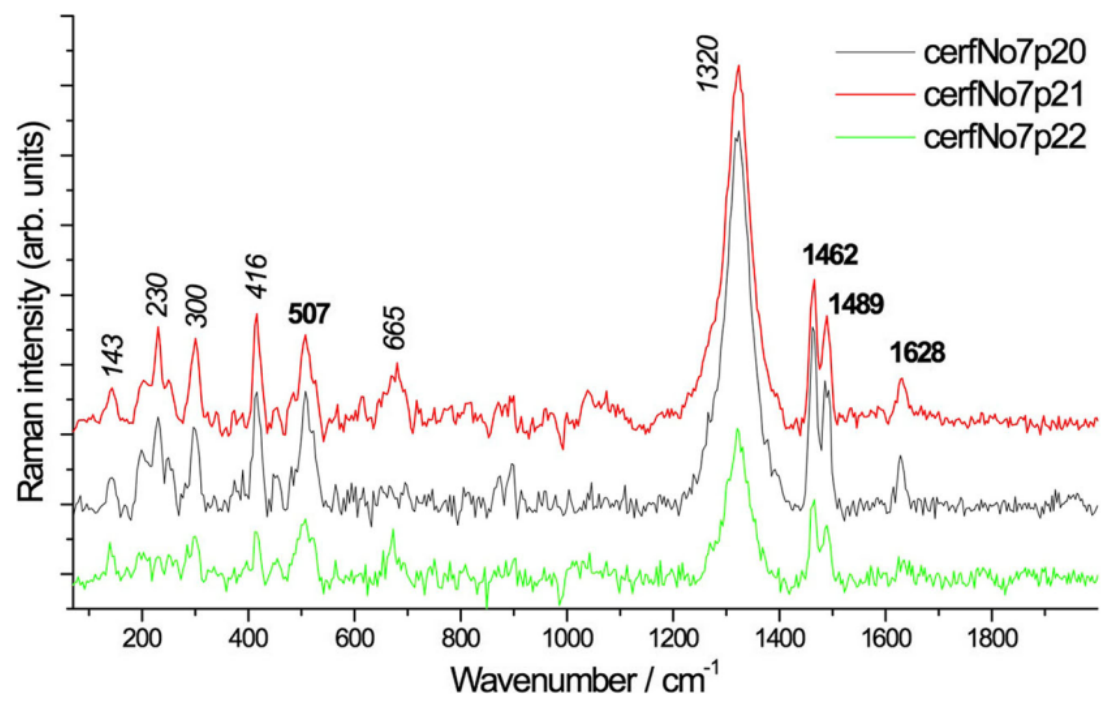

López-Montalvo et al. 2014; Gomes et al. 2015; Rosina et al. 2018, for example). This clear identification only on red areas could be related to the on-site macro observations (paragraph 6a) of various sections, which reveal that the pigment was not buried under alteration layers and that it appears on a naturally polished bedrock surface.

\section{From the study of the microsamples in laboratory}

The mesoscopic observation with an optical microscope of sample RDC2016-P1 from a nondecorated area of the Deer panel enabled us to visualize at least two successive layers: one white, translucent layer (L2), adhering to the bedrock ( $>200$ $\mu \mathrm{m})$, covered by a thinner, yellowish layer (L1-30 $\mu \mathrm{m})$ (Fig. 15). The results obtained on the three microsamples by scanning electron microscopy (SEM) are summarized in Table 3.
A more complex stratigraphy is visible through the observation of the cross-section by SEM: the same external thin layer (L1) and the subdivision of the L2 layer into four sub-layers with varying thicknesses, textures, and superposed morphologies (Fig. 15). The different morphologies could be attributed to alternating environmental precipitation conditions, not yet specified.

Along the cross-section, the chemical composition (SEM-EDX) is still mainly composed of $\mathrm{Ca}$ in association with $\mathrm{Mg}, \mathrm{Si}, \mathrm{Al}, \mathrm{K}$, and $\mathrm{S}$ in varying proportions. A small amount of $\mathrm{Fe}$ could be observed in some layers. The variation of element proportions provides information on the presence of diverse mineral forms, which are yet to be clearly identified. The major presence of $\mathrm{Ca}$ can suggest the presence of calcium oxalate or carbonate minerals. $\mathrm{Ca}$ in association with $S$ suggests a calcium sulfate compound and $\mathrm{Ca}$ associated with $\mathrm{Mg}$ and $\mathrm{Si}$ could be attributed to diopside. Some magnesium or calcium oxides or hydroxides could also be present. A large amount of $P$ was also detected, suggesting
Fig. 14 On-site Raman spectra obtained for deer no5 identifying the red pigment as hematite (excitation $532 \mathrm{~nm}$; pt 2: $10 \mathrm{~s}$ x 10 accumulations, pt. $3: 60 \mathrm{~s}$ x 5 accumulation, spectra are vertically scaled and shifted for presentation). Some very small bands related to whewellite $\left(1462\right.$ and $\left.1489 \mathrm{~cm}^{-1}\right)$ were also observed

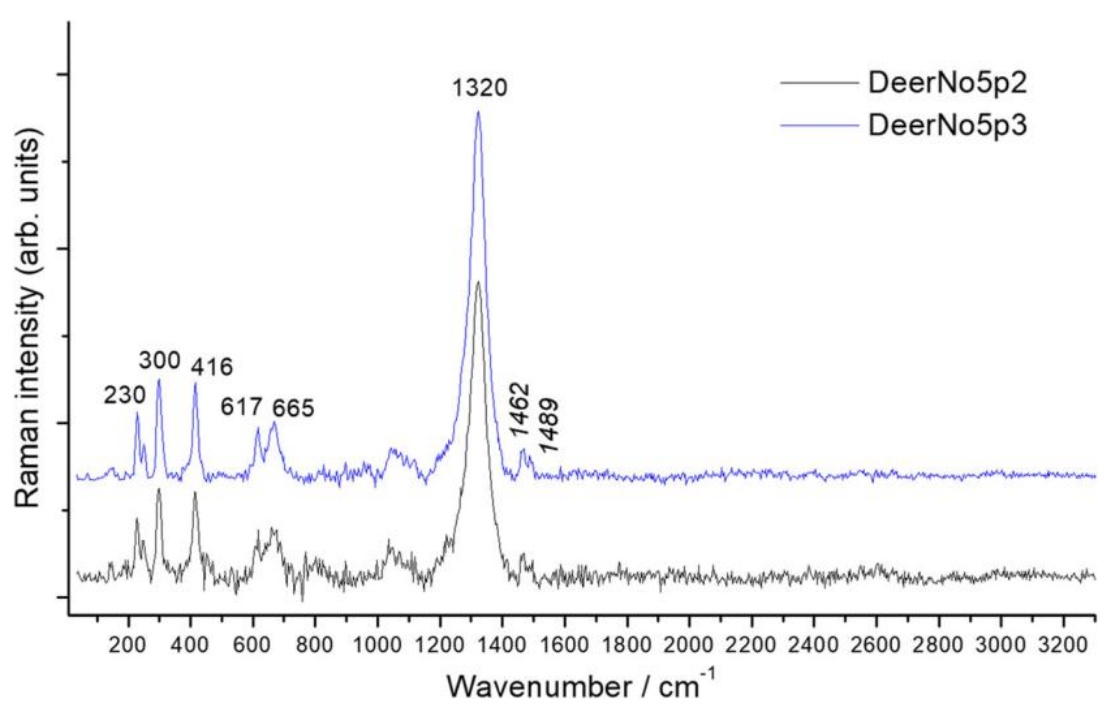



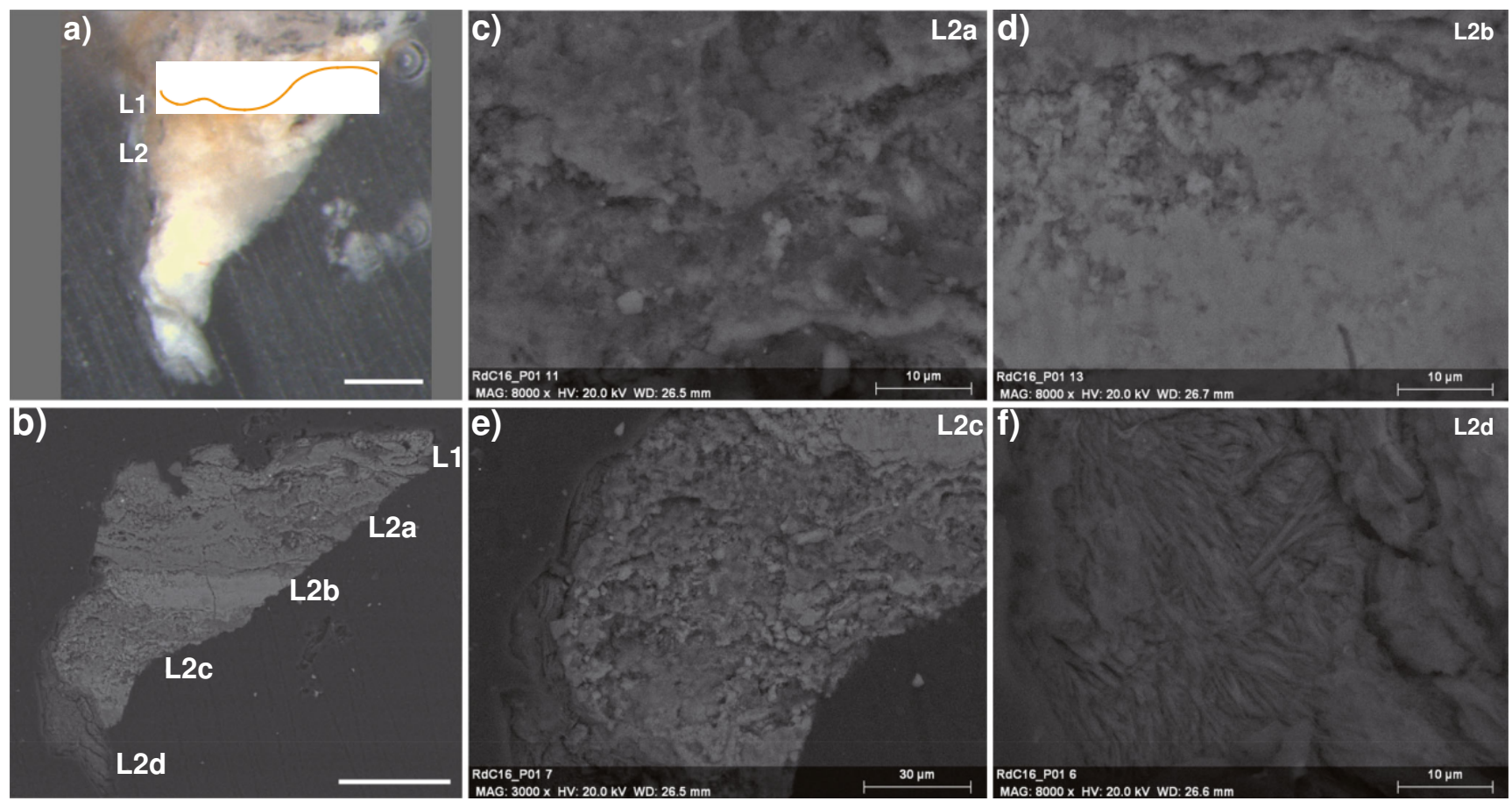

Fig. 15. RDC2016-P1 in cross-section observed by a optical microscopy; b-f) scanning electron microscopy in backscattering electron mode $(20 \mathrm{kV}$, working distance: $26.5 \mathrm{~mm}$ ). Location of each accretion layer and details of

the presence of magnesium and/or calcium phosphates, probably of microbial origin. Arguably, the observation of small regular spherical shells at the surface of sample RDC2016-P3, mainly composed of $\mathrm{Mg}, \mathrm{Ca}$, and $\mathrm{P}$ (ESM 3) confirm this hypothesis. The chemical analysis of the surface of

morphology: c) rare individual geometric particles for layer L2a, d downy morphology for layer L2b, e) smooth particles for layer L2c, and f) lamellar crystals for layer L2d. Created with Illustrator

another sliver from the RDC2016-P1 sample, mounted on a stub, also enables us to confirm the presence of a very thin broken layer of calcium sulfate (like gypsum, $<8 \mu \mathrm{m}$ ) on the top of the surface, which is not visible on the cross-section. These results confirm the hypothesis of a weathering process on the rock surface to form overlapping

Table 3. Results of the micro-samples obtained from the Deer panel (Rocher du Château)

$\mathrm{N}^{\circ} \quad$ Microscopic observation (SEM) Chemical analyses

(EDX)
Proposition of probable mineralogical determination based on SEM-EDX observation

RDC2016-P1 5 sub-layers of white and yellowish accretions:

L1: compact texture without noticeable individual particles

L2a: individual geometric particles $(<5 \mu \mathrm{m})$

L2b: compact texture with downy morphology (as feather)

L2c: granular texture with smooth particles $(<5 \mu \mathrm{m})$

L2d: lamellar crystals $(10 \times 1 \mu \mathrm{m})$

RDC2016-P2 - Thin broken layer $(<8 \mu \mathrm{m})$

- Very thin layer of painting $(2 \mu \mathrm{m})$ constituted by flaky iron oxide $-\mathrm{Fe}_{2} \mathrm{O}_{3}$ particles $(<0,5 \mu \mathrm{m})$

- At least 3 sublayers of accretions with compact or granular textures and different morphologies (geometric, downy or smooth particles)

RDC2016-P3 - Regular spherical shells at the surface $(<3 \mu \mathrm{m}$ in diameter $)$

$-5 \mu \mathrm{m}$ sublayer of downy particles

- $10 \mu \mathrm{m}$ deep sublayer of smooth particles

- Painting layer $(5 \mu \mathrm{m})$ with flaky iron oxide particles $(<0,5 \mu \mathrm{m})$

- Sublayer $(5 \mu \mathrm{m})$ of individual geometric particles $(<2 \mu \mathrm{m})$

- Mixed sublayers of downy and smooth particles
General analysis non correlated with sub-layers:

$\mathrm{Ca}-\mathrm{O} ; \mathrm{Ca}-\mathrm{S}$;

$\mathrm{Ca}-\mathrm{Mg}-\mathrm{Si} ; \mathrm{Mg}-\mathrm{O}$; $\mathrm{Ca} / \mathrm{Mg}-\mathrm{P}$

- $\mathrm{Ca}-\mathrm{S}$

- $\mathrm{Ca}, \mathrm{Mg}, \mathrm{Si}, \mathrm{P}$

- Ca, $M g, S i$

- $\mathrm{Mg}, \mathrm{Ca}$ and $\mathrm{P}$

$-\mathrm{Ca}-\mathrm{S}$

- Ca-P

$-\mathrm{Fe}_{2} \mathrm{O}_{3}$

$-\mathrm{Ca}-\mathrm{O}$

- Ca-P and Ca-S
Minerals not correlated with sub-layers: Whewellite; Gypsum; Diopside; Brucite; Mg Phosphate (newberiyte or bobierite)

- Gypsum

- Hematite

- Diopside

- Whewellite?

- Microbial Mg and Ca phosphate

- Gypsum

- Ca phosphate

- Hematite

- Whewellite

- Ca Phosphate and Gyspum 
layers and are consistent with the compounds observed with Raman spectroscopy (see discussion below in the following section).

Microsampling on two deer figures allowed us to estimate the thickness of the paint layer between 2 and $8 \mu \mathrm{m}$, with an optical microscope (RDC2016-P2 and P3). This layer could be partially covered by a thin yellowish crust layer. The same kind of superposition of white opaque layers is observed underneath the paint sample as for the RDC2016-P1 sample. The description of these underlying layers is summarized in Table 3 . In addition to the elements (SEM-EDX) constituting the underlying layers (Mg, Si, $\mathrm{S}, \mathrm{Ca}, \mathrm{Al}$, and $\mathrm{P}$ ), the chemical composition reveals the presence of $\mathrm{Fe}$ in the paint layer (thickness between 1 and $5 \mu \mathrm{m}$, Figs. 16 and 17). Chemical mapping shows that the phosphorus is not correlated to the iron but strongly related (Fig. 16). The combination of chemical mapping and backscattering electron imagery enables us to visualize the flaky iron oxide particles $(<0.5 \mu \mathrm{m})$ contained in the paint layer (Figs. 16 and 17) for both samples. This observation of iron oxide particles is consistent with the determination of hematite by Raman spectroscopy.

\section{Rock weathering interpretation}

Based on these combined observations at various scales, we can propose an outline of the weathering process before and after the paint was laid on the surface (Fig. 18):

(i) The first step consists in the formation of crust layers by dissolution-precipitation due to water streaming on the serpentinite bedrock surface. The diopside $\left(\mathrm{CaMgSi}_{2} \mathrm{O}_{6}\right)$ mineral identified by Raman spectroscopy is not soluble enough in water to be involved in this process. The water

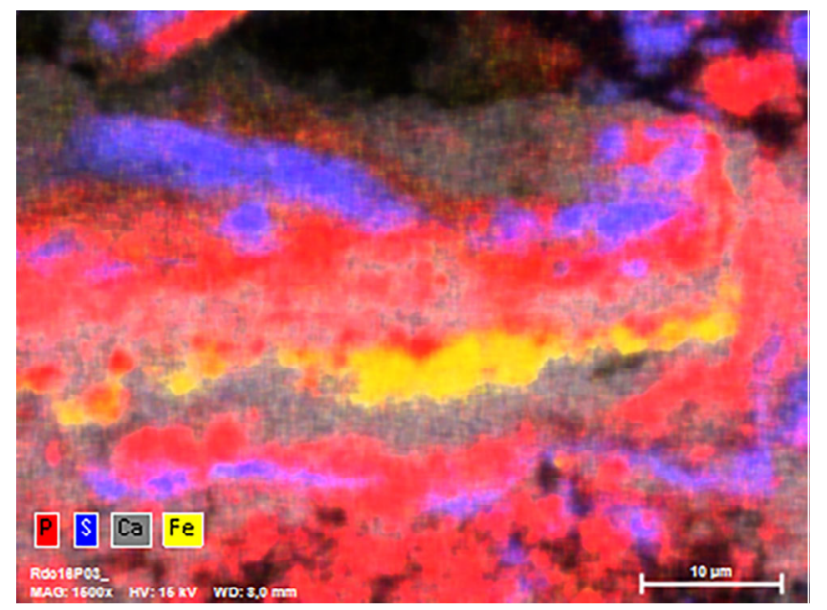

Fig. 17. RDC2016-P3 observed by SEM-FEG-EDX (20 kV, backscattering electron mode), sliver deposed on carbon scotch: chemical mapping realized on the cross-section obtained by sampling (phosphorus in red, sulfur in blue, calcium in gray, and iron in yellow)

flow on the surface can transform the bedrock into soluble minerals and then, during evaporation, can lead to the precipitation of accretion (crust, varnish, coat, or case-hardening), such as calcium and/or magnesium carbonates from the dissolution of the main serpentinite minerals (Cleaves et al. 1974). This phenomenon corresponds to the large white crust layer on the wall due to rainfall or water wash from the upper hill. The presence of gypsum and whewellite also comes from a well-known process. The soluble salt of calcium sulfate develops mainly on surfaces protected from rain and is linked to bacterial and fungal colonies (Tournié et al. 2011). The origin of calcium oxalate (whewellite) is linked to humid atmospheric conditions and metabolic activity (Lamprecht et al. 1997). Therefore, these successive layers could be attributed to distinct climatic periods,

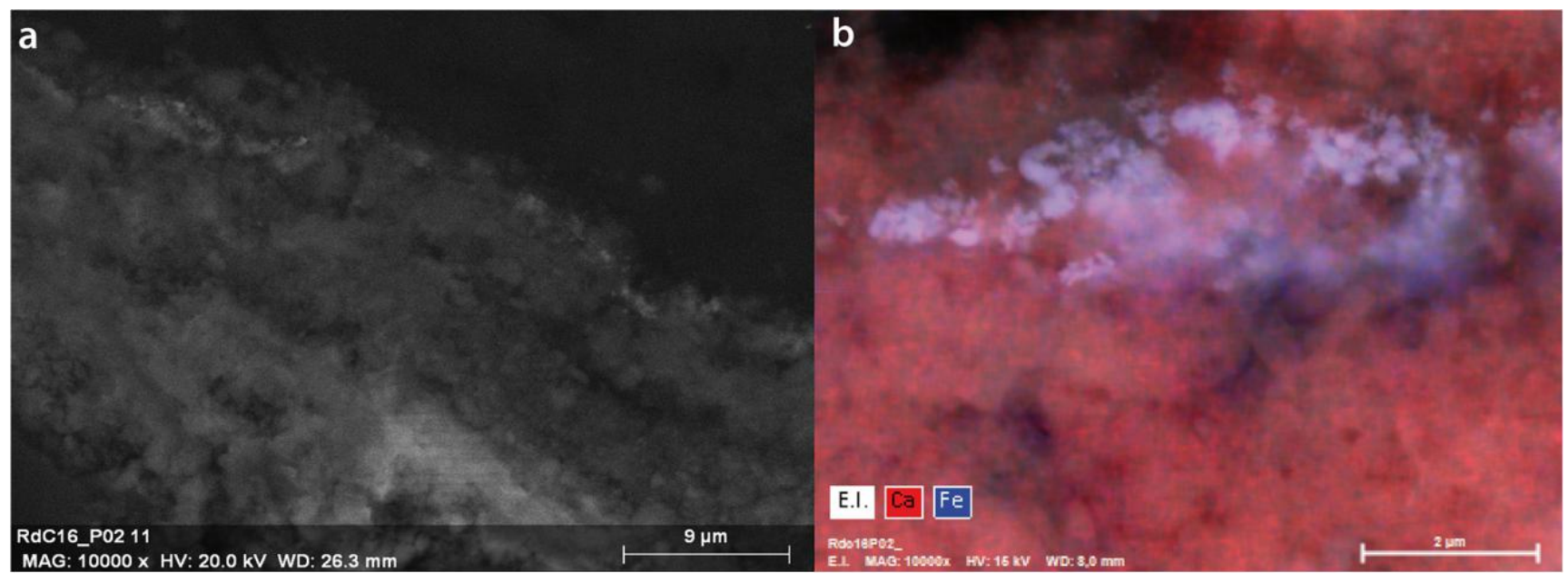

Fig. 16. RDC2016-P2 observed by SEM-FEG-EDX (20 kV, backscattering electron (BSE) mode): a the surface of one sliver deposed on carbon scotch, $b$ a detail of the painting layer on the cross-section chemical mapping (Ca in red, Fe in blue) superposed with BSE image (El in gray) 

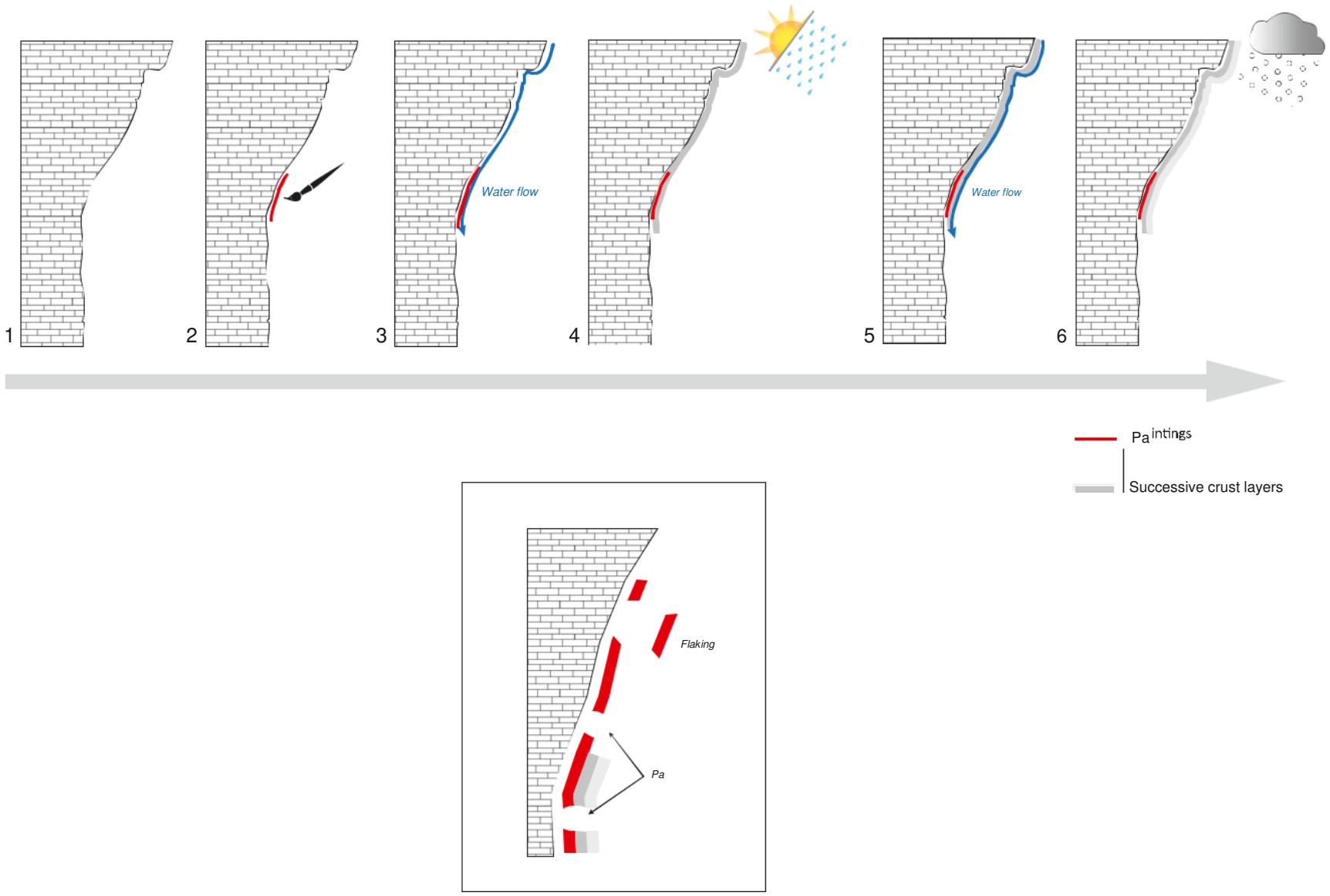

Fig. 18. Proposed sketch of weathering process on the serpentine bedrock of the Rocher du Château

raining or wet, leading to a gradual weathering of the bedrock. Indeed, the variation of air temperature and of air humidity influences the solubility and the crystal growth of salt. The presence of magnesium and/or calcium phosphate phases can be explained by microbial activity, which is confirmed by the spherical morphology observed at the top of the microsample cross-section (SI3).

(ii) The second step of weathering consists in the destruction of the accretion layers with or without an embedded painting layer, either by dissolution or flaking (Figs. 11 and 18b). The flaking could be due to mechanical actions, such as frost in such open-air sites in high altitude, but also to chemical degradation as partial dissolution leading to the leaching of the minerals (Chalmin et al. 2017). This weathering process may also integrate some biological factors, but further studies are needed to confirm it.

\section{Interpretation of the rock painting matter}

The analysis of the painting layer is particularly challenging because of its limited thickness and the complexity of the weathering process. Sample RDC2016-P3 is particularly significant for the understanding of this interweaving between the pigment layer and the crust layer, as suggested by the observation of a non-prepared cross-section (Fig. 17). The thinness $(<5 \mu \mathrm{m})$ of the pigment layer is highlighted by Fe mapping and covered by several accretion layers, suggesting several water flow events, which wash a large part of the painting material before the precipitation of accretion. Due to the weathering process, it is difficult to estimate the presence of extenders or additional minerals with the iron oxide in the preparation of the painting matter.

However, the relation between phosphorus and iron oxide in the painting layer is particularly significant due to the absence of phosphorus in the analyzed substrate. This observation precludes the presence of $P$ in the painting matter on the wall as an environmental signal.

\section{Study of pigments and pigmented materials from the archeological layers}

\section{Results for the pigments}

The macroscopic description of the pigments enables us to distinguish two groups: (i) the two compact nodules(RDC01 and RDC02) and (ii) the cohesive 
and friable matter with a metallic sheen (RDC03-05). The description of the macro and micro-morphology of each pigment is summarized in Table 4, as well as the results obtained with the SEM-EDX analyses. The combination of the morphology and the chemistry confirms the XRD results, which can only attribute an identification of the constituting phases for the matter with a metallic sheen (Table 4, last column).

Group (i) In the RDC01 object, the presence of iron in a matrix of large platelets of phyllosilicate enriched in $\mathrm{K}$ is detected, as well as the presence of $\mathrm{Ca}$. The regular iron oxide crystals $(<20 \mu \mathrm{m})$ from the RDC01 object are clearly different from the smallest rounded irregular particles $(<6 \mu \mathrm{m})$ observed for RDC02, but with a similar chemical composition enriched in $\mathrm{Si}$ and $\mathrm{Ca}$.

The combination of chemistry and micromorphology enables to identify hematite, goethite, and phyllosilicate enriched in $\mathrm{K}$, as muscovite, in the RDC01 nodule. This muscovite is at the origin of the macroscopically shiny appearance. For RDC02, the phyllosilicate enriched in $\mathrm{Mg}$ could be attributed to biotite at the origin of the shiny appearance and associated with iron oxide, such as hematite. The presence of phosphate and calcium occurs in both nodules, but these elements are not correlated and are not attributed to a mineralogical form. In order to

Table 4. Summary of the results obtained by OM, SEM-EDX and by XRD on each coloring matter coming from the excavation of the Rocher du Château (elements of the chemical composition: bold: major; regular: minor; italic: trace; explain the presence of phosphate by taphonomic process during burial (microbial activity or mineral segregation) or by natural or intentional mixture with phosphate mineral, further investigations are required, which involved microsampling of the items.

Group (ii) Optical microscopy reveals the presence of large mica sheets for the three pigments, rounded translucent crystals, fine colored powder, and several embedded charcoals (200-500 $\mu \mathrm{m}$, Fig. 19). For two of them (RDC03 and RDC05), the presence of ligneous elements is also visible. For SEM observation, only the finest fraction $(<100 \mu \mathrm{m})$ was deposited on the carbon adhesive tape. For the XRD analysis, the same fraction was ground for each sample and the predominant presence of quartz and muscovite was confirmed for each sample (ESM 4).

Despite an ostensible similarity at the macroscopic, chemical, and mineralogical levels (ESM 4), various distinctions could be underlined:

- Downy particles of iron oxide (20-100 $\mu \mathrm{m})$ enriched in $\mathrm{Si}, \mathrm{Ca}$, and some $\mathrm{P}$ are only observed in the RDC03 matter (Fig. 20). This poorly crystallized hematite is also detected by XRD (ESM 4) and by FTIR-ATR (Fourier transform infrared in attenuated total reflectance mode, ESM 5).

ND: not determined). Magnetic property was estimated by coming closer a magnet with the archaeological object

\begin{tabular}{|c|c|c|c|c|c|}
\hline $\mathrm{N}^{\circ}$ & Magnetic & Macro-morphology & $\begin{array}{l}\text { Micro- } \\
\text { morphology }\end{array}$ & $\begin{array}{l}\text { Chemical } \\
\text { composition }\end{array}$ & Phases identification \\
\hline RDC01 & No & $\begin{array}{l}\text { Compact nodule with black, red and shinning small } \\
\text { particles at the polished surface. Large modern } \\
\text { incision revealing thin yellow-orange powder inside } \\
\text { the nodule }\end{array}$ & $\begin{array}{l}\text { Smooth regular } \\
\text { crystals }(<20 \\
\mu \mathrm{m}) \text { of Fe } \\
\text { Large platelets } \\
\quad(50 \times 150 \mu \mathrm{m}) \\
\text { of } \mathrm{Al}, \mathrm{Si} \text { and } \mathrm{K}\end{array}$ & $\begin{array}{l}\mathrm{Fe}, \mathrm{Si}, \mathrm{Al}, \mathrm{K} \\
\quad \mathrm{Ca}, P, M g \\
\quad M n\end{array}$ & ND \\
\hline RDC02 & No & $\begin{array}{l}\text { Compact nodule with black and shinning small grains } \\
\text { at the uneven surface. Small modern marks of } \\
\text { incision revealing thin dark red powder inside the } \\
\text { nodule }\end{array}$ & $\begin{array}{l}\text { Rounded } \\
\text { irregular } \\
\text { elementary } \\
\text { particles }(<6 \\
\mu \mathrm{m})\end{array}$ & $\begin{array}{l}\text { Fe, } \mathrm{Si}, \mathrm{Ca} \\
\quad \mathrm{Mg}, K, A l \\
\quad P, M n\end{array}$ & ND \\
\hline RDC03 & Yes & $\begin{array}{l}\text { Friable matter composed by large micas sheets }(>500 \\
\mu \mathrm{m}) \text {, thin red powder }(<10 \mu \mathrm{m}) \text {, rounded translucent } \\
\text { crystals }(<200 \mu \mathrm{m}) \text {, ligneous element }(20 \times 700 \mu \mathrm{m}) \\
\text { and small charcoals }(200-500 \mu \mathrm{m})\end{array}$ & $\begin{array}{c}\text { Downy particles } \\
(20-100 \mu \mathrm{m})\end{array}$ & $\begin{array}{l}\mathrm{Fe}, \mathrm{Si}, \mathrm{Ca}, \mathrm{Al}, \\
\quad \mathrm{P}, K, M g\end{array}$ & $\begin{array}{l}\text { Charcoal + quartz + poorly } \\
\text { crystallized hematite }+ \text { muscovite } \\
\text { + iron silico-phosphate phase }\end{array}$ \\
\hline RDC04 & No & $\begin{array}{l}\text { Friable matter composed by large micas sheets }(2 \mathrm{~mm}) \text {, } \\
\text { thin red powder }(<10 \mu \mathrm{m}) \text {, rounded translucent } \\
\text { crystals }(<200 \mu \mathrm{m}) \text { and small charcoals }(200-500 \\
\mu \mathrm{m})\end{array}$ & $\begin{array}{l}\text { Sharp-feature } \\
\text { crystals } \\
\text { between } 5 \text { and } \\
50 \mu \mathrm{m}\end{array}$ & $\begin{array}{c}\text { Si, Fe, Ca, P, } \\
A l, M g, S\end{array}$ & $\begin{array}{l}\text { Charcoal + muscovite + quartz + } \\
\text { rutile + albite + lizardite + iron } \\
\text { silico-phosphate phase }\end{array}$ \\
\hline RDC05 & Yes & $\begin{array}{l}\text { Friable matter composed by large micas sheets }(>200 \\
\mu \mathrm{m}) \text {, thin red, brownish and white powder }(<10 \mu \mathrm{m}) \text {, } \\
\text { rounded translucent crystals }(<200 \mu \mathrm{m}) \text {, ligneous } \\
\text { element and small charcoals }(200-500 \mu \mathrm{m}) \text { covered } \\
\text { by red thin powder }\end{array}$ & $\begin{array}{l}\text { Sharp-feature } \\
\text { crystals } \\
\text { between } 5 \text { and } \\
50 \mu \mathrm{m}\end{array}$ & $\begin{array}{r}\mathrm{Si}, \mathrm{Al}, \mathrm{Fe}, \mathrm{Ca}, \\
\mathrm{K}, \mathrm{P}, \mathrm{S}, \mathrm{Na}, \\
\mathrm{Mg}, \mathrm{Ti}, \mathrm{Mn}\end{array}$ & $\begin{array}{l}\text { Charcoal }+ \text { muscovite }+ \text { quartz }+ \\
\text { rutile }+ \text { albite }+ \text { lizardite }+ \\
\text { paragonite }+ \text { iron silico-phosphate } \\
\text { phase }\end{array}$ \\
\hline
\end{tabular}


Fig. 19. Small charcoal embedded in red powder observed with a) an optical microscope and b) SEMFEG-EDX (10 kV, BSE) in the RDC04 sample
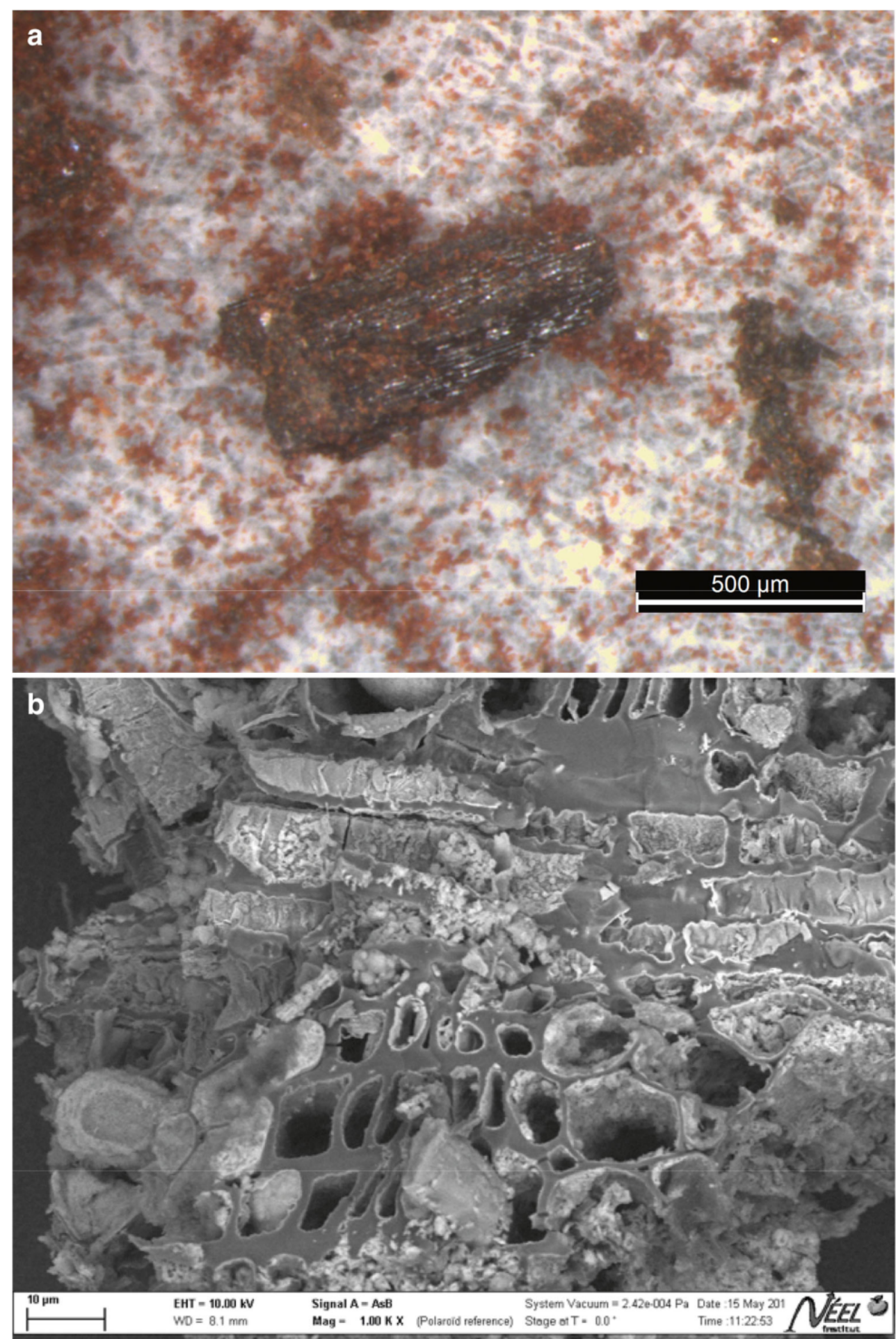

- In the two other materials, RDC04 and RDC05, sharp-featured crystals $(5-50 \mu \mathrm{m})$ containing similar proportions of $\mathrm{Fe}, \mathrm{P}, \mathrm{Ca}$, and $\mathrm{Si}$ (Fig. 20) are very characteristic. This mineralogical phase could be an iron silico-phosphate. On the X-ray diffractogram obtained for the both RDC04 and RDC05, the peaks at 10.8 and 20.6 2theta which could be attributed to this phase are not clearly enough separated from the peaks of the muscovite phase to identify the corresponding structure (ESM 4). The origin of this extremely unusual mineral still remains unknown. Further analyses are required to be able to discriminate and quantify all the mineralogical phases present. 

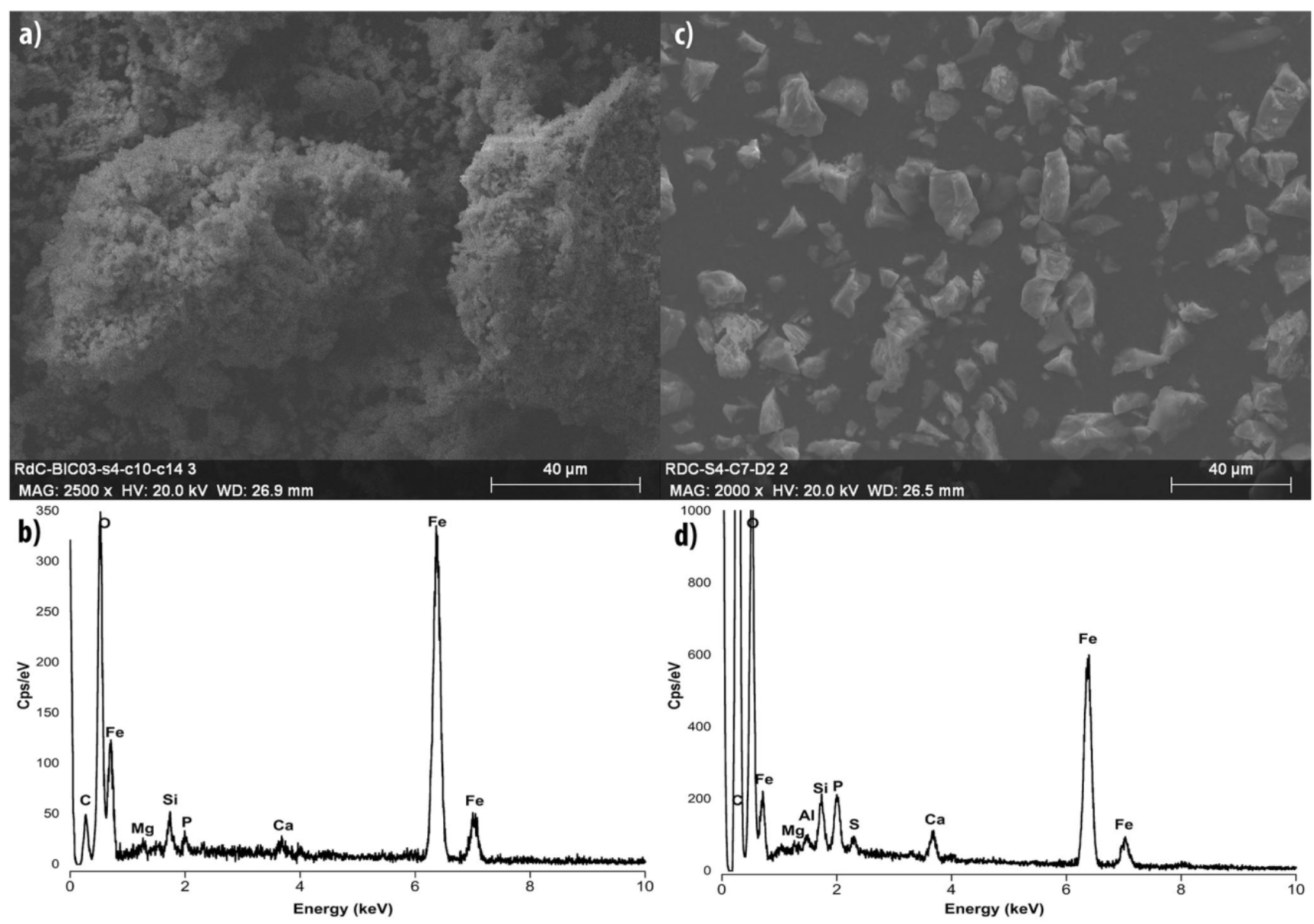

Fig. 20. Results of the SEM-EDX analyses ( $20 \mathrm{kV}$, secondary electron mode) for pigment samples: a) downy particles of iron oxide from RDC03, b) with correlated EDX spectrum, c) sharp-featured crystals of RDC04, d) with correlated EDX spectrum

- The RDC05 material specifically contains traces of several metallic elements $(\mathrm{Cr}, \mathrm{Mn}$, and $\mathrm{Ni})$.

The observation and the analysis of these five pigments confirm the identification of two different kinds of matter despite slight chemical and morphological disparities: (i) the coherent iron oxide mixed with mica minerals (RDC01 and RDC02) and (ii) the friable mixture of large muscovite, small rounded quartz, charcoal, iron silico-phosphate, and potentially hematite (RDC03, RDC04, and RDC05). For all, the origin of the material is clearly exogenous to the sediments of the site. Despite the absence of use-wear traces for all of the items, an anthropogenic mixture is highlighted for the second group of pigments (RDC03, RDC04, and RDC05), because of the presence of small charcoals.

\section{Results for pigmented pebbles}

Observation with an optical microscope reveals the non-planarity of each rough surface for both pigmented pebbles (Fig. 10c, d). The two small pebbles consist in compact polished gneiss with varying proportions of white quartz minerals.
Large cavities contain orange to red matter partially covered by dark sediments. For both pigmented pebbles, the observed surfaces are not suitable for scraping; moreover, no use-wear marks are visible on them. Only sharp traces due to modern manipulation are observed, mainly in the thicker layer of pigments $(<400 \mu \mathrm{m})$ at the surface of the RDC06 pebble (ESM 6). The RDC07 pebble presents a smooth surface without pigment and a pigmented acute-angled edge, which suggests that the wear of the pebble is not linked to the presence of the pigment. For both pebbles, the presence of elements ( $\mathrm{Si}, \mathrm{Al}, \mathrm{K}, \mathrm{Na}$, and $\mathrm{Mg}$ ), which could come from the pebble surface or from the burial environment (sediment with phyllosilicates), is attested by SEMEDX observation (data summarized in the Table 5).

A clear distinction between the pebble surface and the pigments was done thanks to the association of $\mathrm{Fe}, \mathrm{Ca}$, and $\mathrm{P}$ only observed on the pigment. The grain size of the flaky iron oxide does not exceed 5 $\mu \mathrm{m}$ in diameter (ESM 7). The identification of small $\mathrm{TiO}_{2}$ grains, $\mathrm{SiO}_{2}$ crystals (quartz), small rounded $\mathrm{CaCO}_{3}$ grains, and large phyllosilicate platelets enriched in $\mathrm{K}$ (muscovite, $20 \times 7 \mu \mathrm{m}$ ) is confirmed by the morphology and chemical composition of the pigment on both pigmented pebbles. 
Table 5. Summary of the results obtained by OM and SEM-EDX on each pigmented pebble coming from the excavation of the Rocher du Château (elements of the chemical composition: bold: major; regular: minor; italic: trace)

\begin{tabular}{|c|c|c|c|c|}
\hline $\mathrm{N}^{\circ}$ & Macro-morphology of the coloring matter layer & $\begin{array}{l}\text { Micro-morphology of the coloring } \\
\text { matter layer }\end{array}$ & Chemical composition & Phases identification \\
\hline RDC06 & $\begin{array}{l}\text { non-planarity of each rough surface, } \\
\text { thick layer of coloring matter }(<400 \mu \mathrm{m}) \text {, } \\
\text { only sharp modern manipulation mark }\end{array}$ & $\begin{array}{l}\mathrm{SiO}_{2} \text { crystals, small rounded } \\
\mathrm{CaCO}_{3} \text { grains, } \\
\text { and large phyllosilicates } \\
\text { platelets enriched in } \\
\mathrm{K}(20 \times 7 \mu \mathrm{m}), \mathrm{TiO}_{2} \text { grains } \\
\text { flaky iron oxide }(<5 \mu \mathrm{m})\end{array}$ & $\begin{array}{l}\mathrm{Si}, \mathrm{Al}, \mathrm{K}, \mathrm{Ca} \mathrm{P}, \mathrm{Na}, \mathrm{Mg}, \mathrm{Fe}, \\
\mathrm{Mn} \text { and } \mathrm{Ti}\end{array}$ & $\begin{array}{l}\text { quartz, calcite, muscovite, } \\
\text { rutile or anatase }\left(\mathrm{TiO}_{2}\right) \\
\text { and hematite }\end{array}$ \\
\hline RDC07 & $\begin{array}{l}\text { non-planarity of each rough surface, } \\
\text { no use-wear mark, } \\
\text { layer of coloring matter on an acute edge } \\
\quad \text { (thickness not estimated) }\end{array}$ & $\begin{array}{l}\mathrm{SiO}_{2} \text { crystals, small rounded } \\
\mathrm{CaCO}_{3} \text { grains, and } \\
\text { large phyllosilicates platelets } \\
\text { enriched in } \\
\mathrm{K}(20 \times 7 \mu \mathrm{m}), \mathrm{TiO}_{2} \text { grains } \\
\text { flaky iron oxide }(<5 \mu \mathrm{m})\end{array}$ & $\begin{array}{l}\mathrm{Si}, \mathrm{Al}, \mathrm{K}, \mathrm{Ca}, \mathrm{P} \mathrm{Na}, \mathrm{Mg}, \mathrm{Fe} \text {, } \\
\quad \text { and } \mathrm{Ti}\end{array}$ & $\begin{array}{l}\text { quartz, calcite, muscovite, } \\
\text { rutile or anatase }\left(\mathrm{TiO}_{2}\right) \\
\text { and hematite }\end{array}$ \\
\hline
\end{tabular}

Despite strong similarities, the pigments deposited at the surface of the two pebbles present differences in terms of chemical composition. $\mathrm{Mn}$ is only observed on pebble RDC06 and associated with iron oxides. The combination of macroscopic observation and chemical analysis suggests that the deep and chipped pigment at the surface of RDC06 is related to a deposit of wet painting paste composed of hematite. The attribution of the origin of the pigment at the surface of pebble RDC07 is not as obvious as for RDC06. Natural weathering or natural accretion from the burial environment could also explain the presence of this iron-enriched layer, as well as anthropogenic action.

\section{Comparison between the pigments and the pigmented surfaces}

In order to compare the composition of the pigments and the pigmented powders on pebbles or on the cliff, it is necessary to distinguish between the contribution of the object itself, the "environmental signal" (weathering products and/or components from the burial environment), the potential additional components, and the ferruginous components (Chanteraud et al. 2019).

First, a detailed comparison of the pigments distinguishes each material based on differences in macroscopic morphologies and colors, chemical composition, and micro-morphology. The same conclusion could be reached for the pigmented pebble group. For the samples from the paintings, a large heterogeneity of the weathering products and the thinness of the painting layer make their comparison with the pigments and pigmented pebbles delicate.

Nevertheless, for the excavated pigments and painting samples, the presence of hematite is assumed but not clearly identified for all of them. Proof of the presence of hematite has only been obtained on the rock paintings, using in situ Raman analyses, and for the RDC03 sample by FTIR and by XRD analyses, despite a weak crystallinity.
Another way to make correlations between the various pigments and pigmented materials despite the micro-morphology is to identify specific minor chemical elements, such as the manganese observed in RDC01, RDC02, RDC05, RDC06. However, no correspondence could be obtained with the paint from the deer, where no $\mathrm{Mn}$ was detected by SEM-SDX in the stratigraphy of the sampled painting layer. Precaution is needed in interpreting the origin of the $\mathrm{Mn}$, which could come from the burial environment. Complementary analyses of the sediment will be conducted.

Despite the manganese chemical marker, the presence of a specific and unusual phosphate mineral, mainly composed of $\mathrm{Fe}, \mathrm{Si}, \mathrm{Mg}, \mathrm{Al}$, and $\mathrm{P}$ identified in RDC01, RDC02, RDC05, and RDC06 can be used as a pertinent marker for comparison. Indeed, this chemical association is observed in comparable manner both in the rock paintings and in the materials from the SMP culture and suggests a common origin. Notwithstanding, to further advance the study, a structural investigation on the microsamples from the painting layer and the rock substrate is required. The presence of phosphorus associated with iron specifically in the micro-samples from the rock paintings may consequently appear as a clue correlating the rock paintings, the pigments, and the pigmented items from the archeological layers.

The omnipresence of phyllosilicates (mainly muscovite), except in the paint, is also a strong indication of a common origin. Despite a potential common geological origin, the various pigments present morphological, mineralogical, and chemical heterogeneities. Such heterogeneities can be related to the different steps of the chaîne opératoire in order to prepare and modify some properties of the raw material depending on the final use and could also be explained by preservation conditions (Chalmin and Huntley 2017). 
In order to define the geological origin of the raw ferruginous rock with the chemical, morphological, and structural specification, prospection in a large area is now required. A larger project of prospection has begun in various geological deposits (Pigmentothèque project ${ }^{2}$ ).

Several steps for the preparation of the paint itself can be proposed once the composition of the pigments and the pigmented materials in the archeological layers is understood. The presence of charcoal closely blended with iron oxide, muscovite, and an unusual phosphate mineral suggests a deliberate step of mixing. The association of charcoal and hematite has already been observed in Neolithic rock art analyses even if this mixture has been conceived as natural due to fire activity (Gomes et al. 2015). In the present case, the absence of charcoal in the other pigments, pigmented pebbles, and in the painting layers, despite a large quantity of charcoal in the excavated sediments supports the deliberate mixing hypothesis for at least one of the pigments. Depending on the origin of the crystallized iron silicophosphate mineral, the idea of a deliberate mixture can be reinforced.

On the contrary, the possibility of a mixture between a raw iron oxide pigment and an apatite-like component, as proposed in previous studies (for example, burned bones in Hameau 2005) can be excluded as well, because a direct correlation between $\mathrm{Ca}$ and $\mathrm{P}$ has not been demonstrated in the painting layer. A correlation between $\mathrm{Ca}$ and $\mathrm{P}$ is only observed in the crust layer below or above the layer of painting as the result of weathering accretions or as a biomineralization effect. The use of an additional organic agglutinant or binder on the painted layer of rock remains as an outstanding question, even though the thickness of the paint layer and the environment are not conducive to the preservation of an organic compound.

\section{Conclusion}

Several conclusions stem from this integrated study. First, this study of the pigments and pigmented materials from the Rocher du Château site highlights the complementarity of the different methods used. Each of them has its own advantages and limitations and only in combination do they allow full access to the various components of the different materials studied.

Second, this study was performed to provide some chronological argument to the dating of the schematic

2The Pigmentothèque project is supported by the Service Régional de l'Archéologie Auvergne-Rhône-Alpes and is a large collaborative project still in progress aiming at collecting at a national scale the available natural pigment material resources. For further detail see

https://www.researchgate.net/project/Pigmentotheque post-glacial rock paintings by comparing the composition of the pigments and the pigmented pebbles from the archeological layers to that of the rock paintings. Even if a structural investigation is still required to assess this comparison, the presence of a specific and unusual phosphate mineral both in the objects from the archeological layers and in the rock paintings appears as a pertinent marker for comparison. Given the evidence at this stage, the rock art and the archeological pigmented pebbles have arguably the same origin. If these paintings were made in the second half of the 5th millennium $\mathrm{BC}$, the Rocher du Château site provides the oldest chronological argument for such schematic paintings. However, the identical composition of pigments from the dated archeological layers and the paint is not absolute proof of their contemporaneity. An identical composition is only an argument in favor of synchrony between the archeological layers and paintings. An argument provided by the physicochemical analysis of materials that must enter into the overall discussion with all the other archeological facts.

Third, this study revealed that some pigments from the archeological layers dating back to $4600-4000$ BC were prepared by blending natural occurring mineral pigments and organic matter, charcoal in this case. Such an association between mineral and organic elements (such as antler, the fibrous structure of mycoplasmas, apatite from bone and an indeterminate organic compound respectively: Chadefaux et al. 2008; d'Errico et al. 2016; Garate et al. 2004; Rosina et al. 2018) has rarely been evidenced in analyses of rock art samples from the Paleolithic and the Neolithic periods. However, charcoal was generally used for black pigments (for example, López-Montalvo et al. 2014, 2017 and Rosina et al. 2018). The intentional association between hematite and charcoal has never been documented in European prehistory. Therefore, the reasons for such a blend should be questioned. The presence of an unusual crystallized iron silicophosphate mineral reinforces the question of a deliberate mixture and requires further investigations both in micro-samples of rock paintings and on the other pigments and pigmented items. To ensure the possibility of a link between the materials found in the archeological layers and the paint used in each painted panel, the synchrotron based XRD seems to be the most adapted method to detect the presence of this minor or trace constituent in tiny samples with a good spatial resolution. These results allow us to glimpse part of the chaîne opératoire of pigmenting materials since they reveal a common way of preparing them, as well as some specific trace element contents which could be used in future provenance studies of the raw materials. The specific composition of some of the archeological pigments highlights their important potential for comparisons with rock paintings in pending research studies. 
Finally, we highlighted and explained here the taphonomic processes of the painted rock wall. This appears to be essential in order to identify protected areas that should be sampled in the future in order to reinforce comparisons between rock paintings and dated excavated pigments and other pigmented materials.

Research into chronological arguments for the study of schematic rock paintings is necessary to better understand the chrono-cultural context of this graphic expression and to link it to the geography of cultures and ideas during the Neolithic of the Mediterranean region and more generally of western Europe. Indeed, the 5th millennium is characterized by the spread of objects and ideas over long distances, particularly polished green stone axes made from material extracted in the western Alps, probably by the SMP culture groups (Thirault 2005a, b; Pétrequin et al. 2017a, b, c, d). Could part of the schematic paintings be related to this phenomenon? Further studies may question the relationship between the spread of schematic paintings and this long distance artifact diffusion.

Acknowledgments We would like to thank the Bessans municipality and the Service Régional de l'Archéologie Auvergne-Rhône-Alpes for authorizing micro-sampling and supporting fieldwork. Pigment analysis required technical support from various structures and researchers. We thank the ASTRE platform from the Savoie Mont-Blanc University for access to the analytical methods (SEM-EDX and the XRD), the Institut Néel (UPR2940 CNRS/UGA, Grenoble) and particularly Sébastien Pairis for access to the SEMFEG and Pauline Martinetto for her help in the identification phase of the diffractogram. We are also grateful to Catherine Dejoie from the ESRF (European Synchrotron Radiation Facility) ID22 for the XRD study in microbeam of the sample powders and Hélène Salomon (EDYTEM) for her advice and observations of archeological samples. Finally, we would thank Karina Gerdau for the translation service.

Funding information For this study, Claudia Defrasne was funded by a post-doctoral research grant and a contract funded by the Fyssen Fundation from 2014 to 2016, and by Aix-Marseille University-LabexMed from 2016 to 2018.

\section{References}

Arcà A (1995) La Roccia della Fata. In Immagini dalla Preistoria, incisioni e pitture rupestri: nuovi messaggi dalle rocce delle Alpi Occidentali, catalogo della mostra in occasione della XXXVII riunione scientifica I.I.P.P., Corall, Boves, Alba, pp 96-98

Arcà A (1999) Le pitture rupestri della Balma di Mondon, analisi preliminare. B Soc Piemontese Archeo Belle Arti, nuova serie LI: 57-62

Arcà A, Fossati $A E$ (2012) Le pitture rupestri sotto riparo dell'arco alpino, uno sguardo d'insieme. Preistoria Alpina 46(2):173-178
Ayroles P, Porte JL, Barnier M (1984) Saint-Jean-d'Arvey: peintures rupestres. Nouvel abri à peintures de l'Age des Métaux: le Trou de la Féclaz. In 10 ans d'archéologie en Savoie, A.D.R.A.S. Préh et Protoh:44-48

Bellin P (1979) Les Peintures schématiques de la grotte de Levant de Leaunier: l'art schématique ibérique du Ventoux, Buis-les-Baronnies

Bellot-Gurlet L, Neff D, Réguer S, Monnier J, Saheb M, Dillmann P (2009) Raman studies of corrosion layers formed on archeological irons in various media. J Nano Res 8:147-156

Breuil H (1933-1935) Les peintures rupestres schématiques de la Péninsule Ibérique, Fondation Singer-Polignac, Lagny, 3 volumes

Casadio F, Daher C, Bellot-Gurlet L (2016) Raman spectroscopy of Cultural Heritage materials: overview of applications and new fron-tiers in instrumentation, sampling modalities, and data processing. Top Curr Chem 374(5):62113

Chadefaux C, Vignaud C, Menu M, Reiche I (2008) Multianalytical study of Paleolithic reindeer antler. Discovery of antler traces in Lascaux pigments by TEM. Archaeometry 50:516-534

Chalmin E, Huntley J (2017) Characterizing Rock Art Pigments. In David B, McNiven J (eds) The Oxford Handbook of the Archeology and Anthropology of Rock Art, Oxford Handbook. On line. https://doi.org/10.1093/oxfordhb/9780190607357.013.48

Chalmin E, Menu M, Vignaud C (2003) Analysis of rock art painting and technology of Paleolithic painters. Meas Sci Technol 14:1590

Chalmin $E$, Menu $M$, Pomiès $M-P$, Vignaud $C$, Aujoulat $N$, Geneste J-M (2004) Les blasons de Lascaux; The "blazons" of the Lascaux Cave. L'anthropologie 108:571-592

Chalmin E, Hoerlé S, Reiche I (2017) Taphonomy on the Surface of the Rock Wall: Rock-Paint-Atmosphere Interactions. In David B, McNiven J (eds) The Oxford Handbook of the Archeology and Anthropology of Rock Art, Oxford Handbook. On line. https://doi. org/10.1093/oxfordhb/9780190607357.013.47

Chanteraud C, Chalmin E, Hoerlé S, Salomon H, Monney J (2019) Relation entre les matières colorantes issues des fouilles et des parois ornées. Méthodologie et première perspective comparative à la Grotte aux Points (Aiguèze, Gard, France). Karstologia 73:1-12

Cleaves ET, Fisher DW, Bricker OP (1974) Chemical Weathering of Serpentinite in the Eastern Piedmont of Maryland. GSA Bull 85: 437-444

Crosa Lenz P (2001) II Balm d'la Vardaiola. In Crosa-Lenz P (dir) I cacciatori preistorici dell'Alpe Veglia, Edizioni Regione Piemonte-Ente Parco Vegia Devero, pp 51-52

Cuenca-Solana D, Gutiérrez-Zugasti I, Ruiz-Redondo A, González-Morales MR, Setién J, Ruiz-Martínez E, PalacioPérez E, de las Heras-Martín C, Prada-Freixedo A, Lasheras-Corruchaga JA (2016) Painting Altamira Cave? Shell tools for ochre-processing in the Upper Paleolithic in northern Iberia. J Archeol Sci 74:135-151

d'Errico F, Dayet Bouillot L, García-Diez M, Pitarch Martí A, Garrido Pimentel D, Zilhão J (2016) The technology of the earliest European cave paintings: El Castillo Cave, Spain. J Archeol Sci 70:48-65

Darras B (1998) L'image, une vue de l'esprit. Etude comparée de la pensée figurative et de la pensée visuelle. Recherche en Communication 9:77-99

Dayet L, Le Bourdonnec FX, Daniel F, Porraz G, Texier PJ (2015) Ochre provenance and procurement strategies during the Middle Stone Age at Diepkloof Rock Shelter, South Africa. Archaeometry 58(5):807-829

De Giuli A and Priuli A (2012) Le pitture parietali della «Balma dei cervi» in Valle Antigorio: nota preliminare, Oscellana, Edizioni Terre Alte 
De Labriffe PA, Reggio A, Pierre A, Helard B, Guendon JL, Venot R (2017) Mines et Carrières de silex au Néolithique dans le Vaucluse. [Research Report] Service Régional de l'Archéologie Provence-Alpes-Côte-d'Azur

Defrasne C (2014) Digital image enhancement for recording rupestrian engravings: applications to an alpine rockshelter. J Archeol Sci 50: 31-38

Defrasne C, Bailly M (2014) Images in context: a revision of the Oullas panel (Saint-Paul-sur-Ubaye, Alpes de HauteProvence, France). In: Besse M (ed) Around the PetitChasseur Site in Sion (Valais, Switzerland) and New Approaches to the Bell Beaker Culture, Proceedings of the International Conference (Sion, Switzerland - October 27th 30th 2011). Archaeopress, Oxford, pp 101-110

Defrasne C, Chalmin E (2015) Les peintures rupestres du Rocher du Château à Bessans (Savoie). La rubrique des patrimoines de Savoie 36:22-23

Defrasne C, Hameau P (2017) Le point sur l'abri peint de la Gayette. Bull Archeol Prov 38:5-16

Defrasne C, Mocci F, Walsh K, Tzortzis S, Lachenal T, Dumas $\mathrm{V}$ (in press) Vestiges graphiques, culture matérielle et matières premières: circulations du Néolithique aux Ages des Métaux dans les Alpes du Sud (Parc National des Ecrins et Haute-Ubaye, France), in Circulations européennes, circulations montagnardes. Les montagnes: frontières naturelles, frontières culturelles, Paris, éditions du CTHS

Domingo Sanz I (2008) Temporalidad y regionalizacion de las tecnicas de representacion en el Arte Rupestre Levantino, Proceedings of the IV Congreso del Neolitico en la Peninsula Iberica, MARQ, Alacant, pp 22-30

Domingo Sanz I (2015) LRA (Levantine Rock Art). Expression 8:44-50 Domingo I, Villaverde V, López-Montalvo E, Lerma J.L \& Cabrelles M (2013) Latest developments in rock art recording: towards an inte-gral documentation of Levantine rock art sites combining $2 \mathrm{D}$ and $3 \mathrm{D}$ recording techniques. J Archaeol Sci 40(4):1879-1889 Fernández Ruiz M, Spanedda L (2013) Abrigo con arte rupestre de El

Tablazoll (Diezma, Granada). Revisión con DStretch de los motivos pintados. Bastetania 1(9):78-81

Fossati A (2013) L'arte rupestre del Piemonte occidentale (Italia). Alcune osservazioni. In: Sandrone S, Simon P and Venturino Gambari M (eds) Archéologie du passage, Échanges scientifiques en souvenir de Livio Mano, Actes du colloque transfrontalier de Tende - Cuneo, 3-4 août 2012, Editions du musée d'anthropologie préhistorique de Monaco, Monaco, pp 139-152

Fudral S, Deville E, Nicoud G, Pognante U, Guillot PL, Jaillard E (1994) Notice explicative de la feuille Lanslebourg - Mont D’Ambin à 1/ 50000. Editions du BRGM, Service géologique national

Gambari FM (1992) Le pitture rupestri della Rocca di Cavour (TO) e le influenze mediterranee nell'arte rupestre dell'Italia nord-occidentale. In Atti della XXVIII riunione scientifica dell'Istituto Italiano di Preistoria e Protostoria, l'Arte in Italia dal Paleolitico all'età del Bronzo, Firenze, pp. 385-396

Gambari FM (1994) Varzo, loc. Alpe Veglia. Scavi in insediamenti stagionali del Mesolitico e dell'età dei metalli. QuadAPiem 12: 310-311

Gambari FM (1995) Pitture alla Rocca. In Immagini dalla Preistoria, incisioni e pitture rupestri: nuovi messaggi dalle rocce delle Alpi Occidentali, catalogo della mostra in occasione della XXXVII riunione scientifica I.I.P.P., Corall, Boves, Alba, pp 90-94

Gambari FM (2007) Balm d'la Vardaiola: la pittura Neolitica. In di Maio P (ed) Prime Impronte dell'uomo nella regione Sempione - Arbola, Torino, pp 24-25

Gambari F, Arcà A, Cinquetti M, Ricchiardi P, Seglie D (2001) Le pitture rupestri del Pinerolese. Bollettino della Società Piemontese di Archeologia e Belle Arti, LI: 47-70
Garate D, Laval E, Menu M (2004) Etude de la matière colorante de la grotte d'Arenaza (Galdames, Pays Basque, E spagne). L'Anthropologie 108(2):251-289

García Rivero D, Rivero DG, O’Brien MJ (2014) Phylogenetic Analysis Shows That Neolithic Slate Plaques from the Southwestern Iberian Peninsula Are Not Genealogical Recording Systems. PLoS One 9(2):e88296.

Glory A (1941) Quelques peintures ibériques dans l'Ariège, Bull Soc Prehist Midi de la France, pp.165-171

Gomes H, Rosina P, Collado Giraldo H, Garcia Arranz JJ, da Silva Nobre L, Maㅡ Domínguez García I., Rivera Rubio E., Rodríguez Dorado L., Manuel Torrado Cárdeno J., Villalba M., Nacarino de los Santos M (2014) Archaeometric characterization analyses on rock art pig-ments and natural concretions at Friso del Terror- Monfragüe National park, Caceres, Spain. In Sobre rocas y huesos: las societdades prehistoricas y sus manifestaciones platicas. Eds MedinaAlcaide A, Romero Alonso A, Ruiz-Marquez R, Sanchidrian Torti JL, pp 406

Gomes $\mathrm{H}$, Collado $\mathrm{H}$, Martins A, Nash G, Rosina P, Vaccaro C, Volpe L (2015) Pigment in western Iberian schematic rock art: An analytical approach. Mediterr Archaeol Ar 15

Gomes H, Rosina P, Collado Giraldo H and Garcia Arranz JJ (2017a) Analisis Mineralogico de los pigmentos de la Calderita. In Collado Giraldo H and Garcia Arranz JJ (eds) Corpus de Arte Rupestre en Extremadura. Vol IV. Arte Rupestre en la Cornisa de la Calderita, Junta de Extremadura, Consejería de Educación e Igualdad, pp 311 313

Gomes H, Rosina P, Collado Giraldo H and Garcia Arranz JJ (2017b) Sobdeox Arqueologicos en la Cornisa de la Calderita: Resultados Preliminares. In Collado Giraldo H and Garcia Arranz JJ (eds) Corpus de Arte Rupestre en Extremadura. Vol IV. Arte Rupestre en la Cornisa de la Calderita, Junta de Extremadura, Consejería de Educación e Igualdad, pp 311-313

Hameau P (1998) La plaquette gravée de la grotte Monier (Evenos, Var). Annales de la S.S.N.A.T.V. 50(4):225-232

Hameau P, Cruz V, Laval E, Vignaud C et Menu M (2001) Les peintures postglaciaires du sud de la France : recettes picturales. L'anthropologie 105:611-626

Hameau P (2002) Passage, Transformation et Art Schématique. L'exemple des peintures néolithiques du sud de la France. BAR Publishing, Oxford

Hameau P (2005) Des goûts et des couleurs. Chronologie relative et identité culturelle à travers l'analyse des peintures schématiques du Néolithique dans le sudest de la France. Zephyrus 58:195-211

Hameau P (2009) Site, support et signe: une cohérence de sens. L'expression graphique picturale au Néolithique. L'anthropologie 113:861-881

Hameau P (2015) L'eau et le peint: l'élément liquide dans les manifesta-tions picturales du Néolithique. L'Anthropologie 119:106-131 Hameau P, Menu M, Pomies M-P, Walter P (1995) L'art schématique postglaciaire dans le sud-est de la France: analyses pigmentaires. Bull Soc Préhist Fr 92:108119

Hameau P, Cruz V, Laval E, Vignaud C et Menu M (2001) Les peintures postglaciaires du sud de la France: recettes picturales. L'anthropologie 105:611-626

Harman J (2005) Using Decorrelation Stretch to Enhance Rock Art Images. URL. http://www.petroglyphs.us/article_using decorrelation_stretch_to_enhance_rock_art_images.htm/. (accessed 21.06.12)

Hernandez MS (2009) Arte rupestre postpaleolitico en el Arco Mediterraneo de la Peninsula Iberica. Balance de 10 anos de descubrimientos y estudios. In: Lopez JA, Martinez R, Matamoros C (eds) El arte rupestre del Arco Mediterraneo de la Peninsula Iberica. 10 anos en la lista del patrimonio mundial de la UNESCO, Actas IV Congreso (Valencia, 3-45 December 2008). Generalitat Valenciana, Valencia, pp $59-79$ 
Lafuente B, Downs RT, Yang H, Stone N (2015) The power of databases: the RRUFF project. In: Armbruster T, Danisi RM (eds) Highlights in Mineralogical Crystallography. W. De Gruyter, Berlin, pp 1-30

Lamprecht I, Reller A, Riesen R, Wiedemann HG (1997) CaOxalate films and microbiological investigations of the influence of ancient pigments on the growth of lichens. J Therm Anal 49:1601-1607

Le Quellec JL, Harman J, Defrasne C, Duquesnoy F (2013) DStretch et l'amélioration des images numériques: applications à l'archéologie des images rupestres. CAH AARS 17:177-198

Le Quellec JL, Defrasne C, Duquesnoy F (2015) Digital image enhance-ment with DStretch: is complexity always necessary for efficiency? Digit Appl Archeol Cult Herit 2:5567

López-Montalvo E, Villaverde V, Roldán C, Murcia S, BadalGarcía E (2014) An approximation to the study of black pigments in Cova Remigia (Castellón, Spain). Technical and cultural assessments of the use of carbon-based black pigments in Spanish Levantine Rock Art. J Archeol Sci 52:535-545

López-Montalvo E, Roldán C, Badal E, Murcia-Mascarós S, Villaverde V (2017) Identification of plant cells in black pigments of prehistoric Spanish Levantine rock art by means of a multi-analytical approach. A new method for social identity materialization using chaîne opératoire. PLoS One 12(2)

Mano L (1995) Gias delle Pitture, In Immagini alla Preistoria. Incisioni e pitture rupestri: nuovi messagi dalle rocce delle Alpi occidentali, pp 77-80

Marguet A, Bintz P, Nicod PY, Picavet R, Rey PJ, Thirault E (2008) Eléments pour une histoire du peuplement nord-alpin français entre 10,000 et 2700 BP. In: Desmet M (ed) Du climat à l'homme: dynamique holocène de l'environnement dans le Jura et les Alpes. Actes du Colloque GDR JURALP. Aix-en-Provence. Edytem, Université de Savoie, Le Bourget-du-Lac, pp. 225-252

Mark RK and Billo E (2006) Computer-assisted photographic documen-tation of rock art. Coalition CSIC Thematic Network on Cultural Heritage. Electron Newsl 11:10-14

Mas M, Maura R, Solis M (2012) Absolute chronologies and relative chronologies. On the initial sequence of postPaleolithic rock art in the Mediterranean arc. In: Garcia JL, Collado H, Nash G (eds) The Levantine Question: PostPaleolithic rock art in the Iberian Peninsula. Archaeolingua, Budapest, pp 187-207

Müller A, Jorda M, Gassend J-M (2004) L'occupation humaine de la vallée de l'Ubaye et les modalités du peuplement de la zone intra-alpine. Méditerranée 1-2:95-108

Nelh G (1976) Peintures rupestres de Haute-Maurienne (Bessans, Savoie). Bull GERSAR 3:71-76

Nisbet R (1994) Alcuni aspetti dell'ambiente umano nelle Alpi Cozie fra quinto e quarto millennio BP. Monografie di Natura Bresciana 20: 259-271

Padovan S and Thirault E (2007) Les armatures néolithiques en roches polies dans les Alpes occidentales (France - Italie - Suisse): fabri-cation et fonction. In: Daudry D (ed) La pierre en milieu alpin. Actes du Xlème colloque international sur les Alpes dans l'Antiquité, Bagnes, 15-17 septembre 2006. Bulletin de la Société d'Etudes préhistoriques d'Aoste, XVIII: 359-367

Pétrequin $P$, Pétrequin AM, Cinquetti $M$, Nisbet $R$, Tourn Boncoeur S (2017a) Vases à Bouche carrée: le site de « Forte " à Torre Pellice. In Pétrequin P, Gauthier E, Pétrequin AM (eds) JADE, Objets signes et interprétations sociales des jades alpins dans l'Europe néolithique, Presses universitaires de Franche-Comté et Centre de recherche archéologique de la vallée de l'Ain, 17, Dynamiques territoriales, 9 (JADE Tomes 3 et 4), 2017, Cahiers de la MSHE Ledoux, pp. 213-227
Pétrequin P, Mancusi VG, Pétrequin AM (2017b) Vases à Bouche carrée: le site de "Tetto Chiapello » à Valgrana. In Pétrequin P, Gauthier E, Pétrequin AM (eds) JADE, Objets signes et interprétations sociales des jades alpins dans l'Europe néolithique, Presses universitaires de FrancheComté et Centre de recherche archéologique de la vallée de l'Ain, 17, Dynamiques territoriales, 9 (JADE Tomes 3 et 4), 2017, Cahiers de la MSHE Ledoux, pp. 229-245

Pétrequin P, Pétrequin AM, Errera M, Busseuil N, Prodéo F, Chiarenza N (2017c) Alba (Cuneo, Piémont): le mobilier des fouilles anciennes. In Pétrequin P, Gauthier E, Pétrequin AM (eds) JADE, Objets signes et interprétations sociales des jades alpins dans l'Europe néolithique, Presses universitaires de Franche-Comté et Centre de recherche archéologique de la vallée de l'Ain, 17, Dynamiques territoriales, 9 (JADE Tomes 3 et 4), 2017, Cahiers de la MSHE Ledoux, pp 273-322

Pétrequin $P$, Pétrequin AM Cinquetti M, Mancusi VG, Zamagni $B$, Venturino M (2017d) A l'origine des routes du jade alpin: spécialisation régionale des premiers transferts. In Pétrequin P, Gauthier E, Pétrequin AM (eds) JADE, Objets signes et interprétations sociales des jades alpins dans l'Europe néolithique, Presses universitaires de FrancheComté et Centre de recherche archéologique de la vallée de l'Ain, 17, Dynamiques territoriales, 9 (JADE Tomes 3 et 4), 2017, Cahiers de la MSHE Ledoux, pp 323-360

Pons S (1938) Preistoria valdese : di un antico disegno a calcina della Valle Germanasca (Alpi Cozie) e di alcune ricerche affini. Bollettino della società di Studi Valdesi 70:317

Pradeau J-V, Salomon H, Bon F, Mensan R, Lejay M, Regert $M(2014)$ Les matières colorantes sur le site aurignacien de plein air de Régismont-le-Haut (Poilhes, Hérault): acquisition, transformations et utilisations. Bull Soc Prehist Fr 111:631-658

Prieur J (1971) Roches à cupules et gravures rupestres de Maurienne. Bulletin d'Etudes Préhistoriques Alpines 3:141152

Quesada Martínez E (2010) Extensión DStretch del software Image-J. Avance de resultados en el Arte Rupestre de la Región de Murcia. Cuadernos Arte Rupestre 5:14-47

Rey PJ (2009) Sociétés et fluctuations du climat dans les Alpes nord-occidentales au Néolithique moyen. In: Deline P, Ravanel L (eds) Neige et Glace de Montagne: Reconstitution, dynamique, pratiques: Cahiers Edytem, vol 8, pp 37-50

Rey PJ, Moulin B (2011) Premières occupations de la montagne alpine sur les versants du Petit-Saint-Bernard (programme Alpis Graia). Principaux résultats des prospections et sondages archéologiques sur le versant valdôtain (années 2005-2006). Bulletin d'Etudes Préhistoriques et Archéologiques Alpines XXII:9-62

Rey PJ (2016) Eléments pour une approche de l'évolution des styles céramiques entre l'axe Saône-Rhône et les Alpes, de 4500 à 3400 avant notre ère. In Perrin $T$, Chambon $P$, Gibaja JF and Goude G, Le Chasséen, des Chasséens... Retour sur une culture nationale et ses parallèles : Sepulcros de fossa, Cortaillod, Lagozza, Actes du colloque international tenu à Paris (France) du 18 au 20 novembre 2014. Toulouse, pp. 497-535

Rosina P, Gomes H, Collado H, Nicoli M, Volpe L, Vaccaro C (2018) Micro-Raman spectroscopy for the characterization of rock-art pig-ments from Abrigo del Águila (BadajozSpain). Opt Laser Technol 10:274-281

Ruiz JF, Hernanz A, Armitage RA, Rowe MW, Viñas R, GaviraVallejo JM, Rubio A (2012) Calcium oxalate AMS 14C dating and chro-nology of post-Paleolithic rock paintings in the Iberian Peninsula. Two dates from Abrigo de los Oculados (Henarejos, Cuenca, Spain). J Archeol Sci 39:2655-2667 
Salomon H, Coquinot Y, Beck L, Vignaud C, Lebon M, Odin G, Mathis F, Julien M (2014) Stratégies spécialisées d'acquisition de pigments rouges durant le Châtelperronien de la grotte du Renne à Arcy-sur-Cure (Yonne, France). Paléo - Les arts de la Préhistoire: micro-anal-yses, mises en contextes et conservation Actes du colloque "Microanalyses et datations de l'art préhistorique dans son contexte archéologique », MADAPCA - Paris, 16-18 novembre 2011, pp. 125-133

Seglie D, Ricchiardi P (1988) Pitture rupestri di Ponte Raut in Val Germanasca. Survey, Rivista Internazionale di Arte Rupestre ed. Archeol Cogn CeSMAP 3-4:71-73

Seglie D, Ricchiardi P, Cinquetti M (1988) Pitture rupestri preistoriche nel Parco Regionale Rocca di Cavour. Survey, Rivista Internazionale di Arte Rupestre ed. Archeol Cogn CeSMAP 3-4:40-41

Thirault E (2004) Le site néolithique de Bessans / Le Château (Savoie) et la question des armatures perçantes en roches polies dans les Alpes occidentales. In Dartevelle H (eds), Actes de la cinquième session des Rencontres méridionales de Préhistoire récente. Auvergne et Midi Actualité de la recherche, Clermont-Ferrand, 8-9 nov. 2002, Cressensac, pp 421-444

Thirault E (2005a) The politics of supply : the Neolithic axe industry in Alpine Europe. Antiquity 79(303):34-50

Thirault E (2005b) Diffusions de biens et structuration territoriale au Néolithique : le cas des lames de hache en roches tenaces polies dans les Alpes occidentales. In : Jaubert J. et Barbaza M. dir. Territoires, déplacements, mobilité, échanges durant la Préhistoire. Actes du Congrès CTHS de Toulouse, avril 2001. Paris : Editions du Comité des travaux historiques et scientifiques, p. 537-557

Thirault E (2006) Bessans/la Teha (Savoie): présence néolithique à haute altitude $(2250 \mathrm{~m})$ sur les itinéraires transalpins. Bull Soc Prehist Fr 103(4):793-799

Thirault E (2007) Les pointes polies alpines des IV ème et III ème millénaires avant J.-C.: caractérisation archéologique et expérimentale de la chaîne opératoire de fabrication. Bull Soc Prehist Fr 104(1):89-100

Thirault E (2008a) Enjeux et perspectives du Néolithique alpin: l'exemple de la Maurienne (Savoie - France). Palethnologie $1: 410-426$

Thirault E (2008b) Le site néolithique de Bessans / Le Château et ses peintures rupestres. $2^{\circ}$ Congresso Internazionale « Ricerche paletnologiche nelle Alpi occidentali " and $3^{\circ}$ Incontro « Arte rupestre alpina », Pinerolo, 17-19 oct. 2003
Thirault E, Pallier C (2006) Apport de la fouille archéologique du Rocher du Château à la compréhension de la dynamique sédimentaire de la plaine de Bessans (Savoie, France). Travaux Scientifiques du Parc Naturel de la Vanoise 23:65-84

Tournié A, Prinsloo LC, Colomban P, Smith B (2011) The first in situ Raman spectroscopic study of San rock art in South Africa: proce-dures and preliminary results. J Raman Spectrosc 42:399-406

Truchet F (1869) Les Noëls de Bessans. Bulletin de la Société d'Histoire et d'Archéologie de Maurienne $1^{\circ}$ série (II): 376411

Vital J, Benamour P (2012) Économies, sociétés et espaces en Alpe: la grotte des Balmes à Sollières-Sardières (Savoie), Alpara. Publications de la Maison de l'Orient et de la Méditerranée, Lyon

Walsh K, Mocci F, Defrasne C, Dumas V, Masinton A, (2016) Interpreting the Rock Paintings of Abri Faravel: laser and white-light scanning at 2,133m in the southern French Alps. Internet Archaeology (42) 